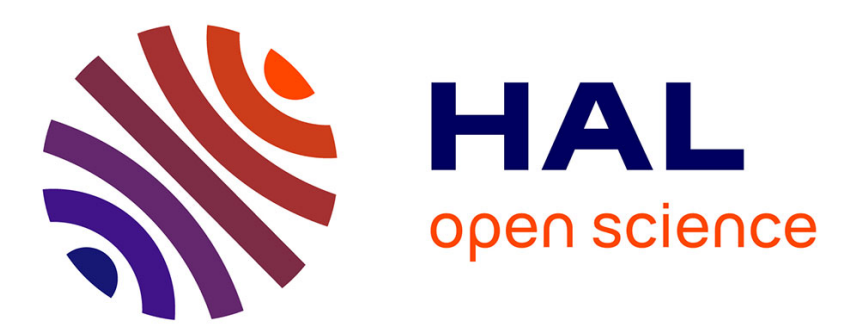

\title{
Dynamic interactions of the 5-HT 6 receptor with protein partners control dendritic tree morphogenesis
}

Camille Pujol, Vincent Dupuy, Martial Séveno, Léonie Runtz, Joël Bockaert, Séverine Chaumont-Dubel, Philippe Marin

\section{- To cite this version:}

Camille Pujol, Vincent Dupuy, Martial Séveno, Léonie Runtz, Joël Bockaert, et al.. Dynamic interactions of the 5-HT 6 receptor with protein partners control dendritic tree morphogenesis. Science Signaling, 2020, 13 (618), pp.eaax9520. 10.1126/scisignal.aax9520 . hal-02485360

\section{HAL Id: hal-02485360 \\ https://hal.science/hal-02485360}

Submitted on 21 Nov 2020

HAL is a multi-disciplinary open access archive for the deposit and dissemination of scientific research documents, whether they are published or not. The documents may come from teaching and research institutions in France or abroad, or from public or private research centers.
L'archive ouverte pluridisciplinaire HAL, est destinée au dépôt et à la diffusion de documents scientifiques de niveau recherche, publiés ou non, émanant des établissements d'enseignement et de recherche français ou étrangers, des laboratoires publics ou privés. 


\title{
Dynamic interactions of the 5-HT 6 receptor with protein partners control dendritic tree morphogenesis
}

\author{
Camille N. Pujol ${ }^{1}$, Vincent Dupuy ${ }^{1}$, Martial Séveno ${ }^{2}$, Leonie Runtz ${ }^{1,3}$, Joël Bockaert ${ }^{1}$, Philippe \\ Marin $^{1 * \dagger}$ Séverine Chaumont-Dubel ${ }^{1 * \dagger}$
}

${ }^{1}$ Institut de Génomique Fonctionnelle, Université de Montpellier, CNRS, INSERM, Montpellier, France. ${ }^{2}$ BioCampus Montpellier, Université de Montpellier, CNRS, INSERM, Montpellier, France. ${ }^{3}$ Department of Psychiatry, McGill University, Douglas Hospital Research Center, Montreal, Canada.

*These authors contributed equally to this work.

${ }^{\dagger}$ Corresponding author. Email: philippe.marin@igf.cnrs.fr $\quad$ (P.M.); severine.chaumontdubel@,igf.cnrs.fr (S.C.-D.)

\begin{abstract}
The serotonin (5-hydroxytrypatmine) receptor $5-\mathrm{HT}_{6}\left(5-\mathrm{HT}_{6} \mathrm{R}\right)$ has emerged as a promising target to alleviate the cognitive symptoms of neurodevelopmental diseases. We previously demonstrated that the 5- $\mathrm{HT}_{6} \mathrm{R}$ finely controls key neurodevelopmental steps, including neuronal migration and the initiation of neurite growth, through its interaction with cyclin-dependent kinase $5(\mathrm{Cdk} 5)$. Here, we showed that the $5-\mathrm{HT}_{6} \mathrm{R}$ recruited $\mathrm{G}$ protein-regulated inducer of neurite outgrowth 1 (GPRIN1) through a Gs-dependent mechanism. Interactions between the receptor and either Cdk5 or GPRIN1 occurred sequentially during neuronal differentiation. The 5-HT 6 R-GPRIN1 interaction enhanced agonist-independent, receptor-stimulated cAMP production without altering the agonist-dependent response in NG108-15 neuroblastoma cells, meaning that neither the affinity for the agonist nor the maximum response to the agonist is changed. This interaction also promoted neurite extension and branching in NG108-15 cells and primary neurons through a PKA-dependent mechanism. This study highlights the complex allosteric modulation of GPCRs by protein partners and demonstrates how GPCR dynamic
\end{abstract}


interactions with protein partners can control the different steps of highly coordinated cellular processes, such as dendritic tree morphogenesis.

\section{Introduction}

Over the last two decades, it has become evident that G protein-coupled receptors (GPCRs) do not solely recruit canonical signaling proteins, such as heterotrimeric $\mathrm{G}$ proteins and $\beta$-arrestins (1), but that they also interact with large networks of intracellular proteins that finely control their targeting to specific subcellular compartments, their trafficking in and out of the plasma membrane, and their signaling (2-5). These complexes have been extensively described for certain GPCRs by means of unbiased interactomics screens $(2,3,6,7)$ and often include several proteins that interact with common binding sites within a given GPCR, stressing the importance of spatiotemporal regulation of the interactions of GPCRs with their protein partners in their pathophysiological functions. However, the dynamics of the associations of GPCRs with interacting proteins and their functional outcomes remain poorly characterized.

The serotonin (5-hydroxytryptamine) receptor $5-\mathrm{HT}_{6}\left(5-\mathrm{HT}_{6} \mathrm{R}\right)$ is a Gs-coupled receptor exclusively expressed in the nervous system. The highest receptor densities are found in regions involved in mnemonic functions (8-12). Consistent with this particular distribution, the $5-\mathrm{HT}_{6} \mathrm{R}$ has emerged as a promising target to alleviate the cognitive symptoms of various neurological and psychiatric disorders (13). 5- $\mathrm{HT}_{6} \mathrm{R}$ blockade relieves deficits in a wide range of models of cognitive impairment in rodents, and preliminary clinical studies have unequivocally shown procognitive effects of several $5-\mathrm{HT}_{6}$ receptor antagonists in humans (14-17). However, any initial hope has been tempered by the failure of phase III trials of the leading compound 
idalopirdine ( $\mathrm{Lu} \mathrm{AE58054)}$ used in conjunction with the acetylcholine esterase inhibitor donepezil in patients with Alzheimer's disease (18).

The $5-\mathrm{HT}_{6} \mathrm{R}$ is also expressed early during neuronal development, and studies have demonstrated its crucial role in both the correct migration and positioning of neurons, neurite growth, and neuronal differentiation $(19,20)$. Further lines of evidence showed that most of the effect of the receptor on neuronal development is independent of its coupling to Gs, suggesting the involvement of alternative signaling mechanisms (21). To address this issue, genetic and proteomics strategies were used to characterize the $5-\mathrm{HT}_{6} \mathrm{R}$ interactome $(20,22-27)$. These studies showed that the receptor interacts with several proteins of the mechanistic target of rapamycin (mTOR) pathway, including mTOR itself, and that 5-HT 6 R-elicited mTOR activation in the prefrontal cortex underlies cognitive deficits in neurodevelopmental models of schizophrenia in rodents $(25)$. These studies also revealed that the $5-\mathrm{HT}_{6} \mathrm{R}$ recruits cyclindependent kinase 5 (Cdk5), as well as several of its targets that are involved in neurite growth and synaptogenesis (20). The interaction between $5-\mathrm{HT}_{6} \mathrm{R}$ and $\mathrm{Cdk} 5$ induces the phosphorylation of the receptor by $\mathrm{Cdk} 5$, which promotes the initiation of neurite growth through a Cdc42dependent pathway (20). Further experiments showed that the $5-\mathrm{HT}_{6} \mathrm{R}$ also controls neuronal migration through a Cdk5-dependent mechanism (19).

Another important feature of the $5-\mathrm{HT}_{6} \mathrm{R}$ is its high level of constitutive activity, which was established not only for recombinant receptors expressed in cell lines (28), but also for native receptors in cultured neurons and mouse brain (29). Furthermore, the receptor constitutively activates not only the canonical Gs signaling pathway, but also Cdk5 signaling through a 
mechanism dependent on receptor phosphorylation by associated Cdk5 (20), highlighting the potential influence of GPCR-interacting proteins upon GPCR constitutive activity. One of the Cdk5 substrates known to control neurodevelopmental processes identified in the 5- $\mathrm{HT}_{6} \mathrm{R}$ interactome is G protein-regulated inducer of neurite outgrowth 1 (GPRIN1), which is a member of a protein family consisting of three gene products (GPRIN1 to GPRIN3) (30). GPRIN1 is highly abundant in the brain, binds selectively to activated G proteins, and promotes neurite extension (30-32). Several lines of evidence suggest that GPRIN1 promotes neurite growth through its direct interaction with membrane-bound receptors $(32,33)$.

Here, we demonstrated that $5-\mathrm{HT}_{6} \mathrm{R}$ interacted sequentially with Cdk5 and GPRIN1 during the differentiation of NG108-15 neuroblastoma cells. Functional studies showed that the interaction between the $5-\mathrm{HT}_{6} \mathrm{R}$ and GPRIN1 potentiated $5-\mathrm{HT}_{6} \mathrm{R}$ constitutive activity and promoted neurite elongation and branching in an agonist-independent, but cAMP-dependent, manner in both neuroblastoma cells and primary striatal neurons. Together, these findings suggest that the 5$\mathrm{HT}_{6} \mathrm{R}$ promotes neuronal differentiation through sequential engagement of different signaling pathways that depends on agonist-independent allosteric receptor activation by distinct interacting proteins.

\section{Results}

\section{The 5-HT ${ }_{6} \mathrm{R}$ forms a complex with GPRIN1 in mouse brain}

Using an Affinity Purification-Mass Spectrometry (AP-MS) proteomic approach and the 5- $\mathrm{HT}_{6} \mathrm{R}$ C-terminal domain as bait, we previously demonstrated the physical association of the $5-\mathrm{HT}_{6} \mathrm{R}$ with a network of proteins known to control key neurodevelopmental processes, such as the 
migration of neurons and neurite growth. These interaction partners include Cdk5 and some of its regulators and substrates, such as GPRIN1 (Fig. 1A). Given the developmental pattern of 5$\mathrm{HT}_{6} \mathrm{R}$ and GPRIN1 expression $(8,34)$ and their common influence upon neuronal differentiation $(20,32,35)$, we first confirmed the existence of the $5-\mathrm{HT}_{6} \mathrm{R}-\mathrm{GPRIN} 1$ interaction in the brains of new-born mice, taking advantage of knock-in (KI) mice expressing the $5-\mathrm{HT}_{6} \mathrm{R}$ fused to green fluorescent protein (GFP; 5-HT 6 R-GFP) (29). GPRIN1 coimmunoprecipitated with 5-HT 6 R-GFP from brain protein extracts, indicating an association between the receptor and GPRIN1 (Fig. 1B). Corroborating these findings, immunohistochemistry combined with confocal microscopy showed the co-localization of the receptor and GPRIN1 in the soma of striatal (Fig. 1C) and cortical (fig. S1A) neurons from new-born 5-HT 6 R-GFP KI mice. Consistent with previous findings that showed expression of the $5-\mathrm{HT}_{6} \mathrm{R}$ in the primary cilium (36-39), GFP immunostaining was also detected on cilia-like processes positively stained with an antibody against Arl13b (fig. S1A), a cilial marker, in both the striatum and cortex, but no co-localization between $5-\mathrm{HT}_{6} \mathrm{R}$ and GPRIN1 was found in primary cilium. Amplifying the signal from the GFP antibody also uncovered a small population of receptor that displayed a somato-dendritic localization in cultured striatal neurons from 5-HT6 R-GFP-KI mice, but not wild-type mice. Furthermore, these somato-dendritic receptors were colocalized with GPRIN1 (fig. S1B).

\section{The 5-HT 6 R sequentially interacts with Cdk5 and GPRIN1 in NG108-15 cells}

Our interactomic screen showed that both Cdk5 and GPRIN1 interact with the 5-HT 6 receptor Cterminal domain (20). To better characterize the dynamics of these interactions and to explore whether they occurred simultaneously or were exclusive, we performed immunoprecipitation experiments in NG108-15 cells transfected with cDNAs encoding 5-HT 6 R and either GPRIN1 or 
Cdk5. In cells co-expressing GPRIN1 and 5- $\mathrm{HT}_{6} \mathrm{R}$, we detected an interaction by immunoprecipitation 24 hours after transfection of the cells with both cDNAs, which was statistically significantly increased after 48 hours (Fig. 1D and fig. S2A). In contrast, although we observed an interaction between the receptor and Cdk5 24 hours after transfection, this was followed by dissociation of the complex 48 hours after transfection, as shown by coimmunoprecipitation experiments (Fig. 1E and fig. S2B). These findings were confirmed with bioluminescence resonance energy transfer (BRET)-based assays (Fig. 1F): a specific BRET signal was detected in NG108-15 cells co-expressing 5-HT 6 R-YFP and Cdk5 24 hours after transfection, whereas no interaction between the two proteins was detected 48 hours after transfection. These results indicate that the receptor sequentially interacts with $\operatorname{Cdk} 5$ and GPRIN1 in NG108-15 cells, suggesting that the receptor's interaction partners are dynamically regulated.

Because Cdk5 phosphorylates the $5-\mathrm{HT}_{6} \mathrm{R}$ on serine $350\left(\mathrm{Ser}^{350}\right)$, we wondered whether this phosphorylation event modulated the interaction between the receptor and GPRIN1. We found that a receptor having a mutation that prevented the phosphorylation of the receptor by $\mathrm{Cdk} 5$ (S350A mutant) interacted to a greater extent with GPRIN1 than did the wild-type receptor (fig. S3A). In contrast, a mutant mimicking the phosphorylation of $\operatorname{Ser}^{350}$ (S350D) did not interact with GPRIN1. Similarly, over-expressing p35, a coactivator of Cdk5, to enhance Ser ${ }^{350}$ phosphorylation, reduced the association between wild type 5-HT6 $\mathrm{R}_{6}$ with GPRIN1 (fig. S3, A and B). This suggests that the $5-\mathrm{HT}_{6} \mathrm{R}$ is unable to interact with GPRIN1 when it is phosphorylated by Cdk5. 


\section{The association between GPRIN1 and the 5-HT 6 depends on $G$ proteins and the conformational state of the receptor}

The amount of GPRIN1 that co-immunoprecipitated with a mutant of the 5- $\mathrm{HT}_{6} \mathrm{R}$ unable to activate $\mathrm{G}$ proteins [the triple mutant F69L T70D D72A, (40)] or a mutant 5-HT 6 R lacking the C-terminal domain ( $\Delta$ Cter) was statistically significantly reduced when compared to the amount of GPRIN1 that co-immunoprecipitated with the full-length, wild-type receptor (Fig. 1G and fig. S2C). Combining the triple mutation with the C-terminal deletion abolished the ability of the receptor to co-immunoprecipitate with GPRIN1, suggesting that both the C-terminal domain of the receptor and the ability of the receptor to activate $G$ proteins are required for formation of the 5-HT6R-GPRIN1 complex (Fig. 1G). To confirm the involvement of the receptor C-terminal domain in the 5-HT6-R-GPRIN1 interaction, we attempted to immunoprecipitate the wild-type receptor and GPRIN1 from cells treated with an interfering peptide corresponding to residues 320 to 342 of the $\mathrm{C}$-terminal tail of $5-\mathrm{HT}_{6} \mathrm{R}$ fused to the transduction domain of the HIV TAT protein (TAT-Ct320-342 peptide). Reminiscent of the effect of the C-terminal domain truncation, exposing cells to the TAT-Ct320-342 peptide reduced the amount of GPRIN1 that coimmunoprecipitated with the $5-\mathrm{HT}_{6} \mathrm{R}$ when compared to that in cells cells exposed to a control peptide (Fig. 1H and fig. S2D). Finally, the amount of GPRIN1 that co-immunoprecipitated with the 5- $\mathrm{HT}_{6} \mathrm{R}$ was reduced by exposing cells to the 5-HT 6 R antagonist SB271046 (Fig. 1I and fig. $\mathrm{S} 2 \mathrm{E}$ ), which behaves as an inverse agonist with respect to receptor-operated Gs signaling, suggesting that the binding of GPRIN1 to the $5-\mathrm{HT}_{6} \mathrm{R}$ is a dynamic process which depends on the conformational state of the receptor. 


\section{The interaction between GPRIN1 and the 5-HT 6 R enhances receptor constitutive activity}

We previously demonstrated that the $5-\mathrm{HT}_{6} \mathrm{R}$ exhibits constitutive activation of the Gs pathway in NG108-15 neuroblastoma cells, as well as in striatal neurons $(20,29)$. Using the CAMYEL cAMP BRET sensor (41), we found that co-expressing GPRIN1 with the 5- $\mathrm{HT}_{6} \mathrm{R}$ did not change basal cAMP production 24 hours after transfection of the NG108-15 cells, whereas it enhanced agonist-independent cAMP production 48 hours after transfection (Fig. 2A). These findings are consistent with our earlier immunoprecipitation experiments showing that the extent of the interaction between the receptor and GPRIN1 was greater 48 hours after transfection than at 24 hours after transfection. Further functional studies of the $5-\mathrm{HT}_{6} \mathrm{R}-\mathrm{GPRIN} 1$ interaction were thus performed 48 hours after transfection. Consistent with a role for this interaction in the constitutive activity of the receptor, potentiation of $5-\mathrm{HT}_{6} \mathrm{R}-$ dependent cAMP production in cells co-expressing GPRIN1 was inhibited when the cells were treated with the TAT-Ct320-342 peptide (Fig. 2A). Moreover, the apparent affinity and efficacy of the inverse agonist SB271046 in inhibiting 5- $\mathrm{HT}_{6} \mathrm{R}$-dependent cAMP production were reduced in cells co-expressing GPRIN1 (Fig. 2B), suggesting that the binding of GPRIN1 may stabilize the receptor in an active conformation that exhibits a reduced affinity for inverse agonists. When cells were treated with the 5-HT6R agonist WAY181187, they produced similar amounts of cAMP irrespective of the presence or absence of GPRIN1 (Fig. 2B), suggesting that constitutive, but not agonistdependent cAMP production, depended on the physical interaction of the receptor with GPRIN1 (Fig. 2B).

To further confirm that only the constitutive and not the agonist-dependent activity of the receptor was modulated by its interaction with GPRIN1, we engineered a 5-HT 6 R mutated at a 
tryptophan residue in the sixth transmembrane domain of the receptor (W281A), because previous studies indicate that the corresponding tryptophan residue in $5-\mathrm{HT}_{4} \mathrm{R}$ is essential for the constitutive activity of that receptor (42). As expected, the constitutive activity of the W281A mutant $5-\mathrm{HT}_{6} \mathrm{R}$ was reduced compared to that of the wild-type receptor, whereas the agonistdependent activity was not affected (Fig. 2C). Furthermore, GPRIN1 was unable to potentiate the residual constitutive activity of the W281A mutant 5- $\mathrm{HT}_{6} \mathrm{R}$. Immunoprecipitation experiments showed that mutation of $\operatorname{Trp}^{281}$ reduced the extent of the interaction between the receptor and GPRIN1 (Fig. 2D and fig. S2F), suggesting that GPRIN1 may not only enhance the constitutive activity of the $5-\mathrm{HT}_{6} \mathrm{R}$, but also preferentially associate with the receptor when it is in its active conformational state.

The increase in the constitutive activity of the receptor could result from either the increased recruitment of activated $\mathrm{G}$ protein by the receptor in the presence of GPRIN1 or from an increase in abundance of the receptor at the plasma membrane. To discriminate between these two possibilities, we compared the membrane abundance of the receptor in NG108-15 cells in the presence or absence of GPRIN1. We found no substantial difference in the membrane abundance of the receptor in either cell population (fig. S4). Furthermore, the amount of Gs protein that coimmunoprecipitated with the receptor was increased in the presence of GPRIN1, an effect that was prevented by treatment of the cells with the TATCt320-342 peptide (Fig. 2E and fig. S2G). These results suggest that the GPRIN1-dependent increase in 5- $\mathrm{HT}_{6} \mathrm{R}$ constitutive activity results from an enhanced Gs signaling by the receptor rather than an increase in its abundance at the plasma membrane. 


\section{GPRIN1 enhances 5-HT 6 R-dependent neurite elongation and branching in NG108-15 cells}

We previously demonstrated that the $5-\mathrm{HT}_{6} \mathrm{R}$ induces the initiation of neurite growth in NG10815 cells in a ligand- and cAMP-independent manner, through a Cdk5-Cdc42 pathway (20). Consistent with previous studies showing that GPRIN1 can also induce neurite growth (31-33), we sought to determine whether GPRIN1 promoted neurite growth in NG108-15 cells expressing the 5-HT ${ }_{6} \mathrm{R}$. Immunocytochemistry experiments with NG108-15 cells transfected with cDNAs encoding either GFP or the GFP-fused receptor, alone or in combination with GPRIN1, showed that 24 hours after transfection, co-expression of GPRIN1 did not further increase the length of neurites when compared to the length of neurites produced by cells expressing the receptor alone (Fig. 3A). Consistent with our previous findings, 5- $\mathrm{HT}_{6} \mathrm{R}$-dependent neurite growth was reduced when a dominant-negative mutant $\mathrm{Cdk} 5$ was co-expressed (Fig. 3A), suggesting that the initiation of neurite growth did not depend on the presence of GPRIN1 but required the kinase activity of Cdk5. In contrast, 48 hours after transfection, cells expressing both $5-\mathrm{HT}_{6} \mathrm{R}$ and GPRIN1 exhibited longer and more branched neurites than did cells expressing the receptor alone, as determined by immunocytochemistry and quantified by Sholl analysis (Fig. 3A). Furthermore, co-expression of the dominant-negative mutant Cdk5 did not affect the GPRIN1induced increase in branching at that stage of neuronal differentiation, although a residual effect on neurite length was seen (Fig. 3B). This suggests that the branching of neurites does not require the activity of $\mathrm{Cdk} 5$ and is consistent with our results showing that $\mathrm{Cdk} 5$ does not interact with the receptor 48 hours after transfection.

Treating cells co-expressing 5-HT6 and GPRIN1 with the TAT-Ct320-342 peptide or coexpressing the 5-HT6 $\mathrm{R}$ S350D mutant with GPRIN1 abolished the effect of GPRIN1 on both 
neurite extension and branching (Fig. 3, A and B and fig. S3C), indicating that the growthpromoting effects of GPRIN1 depended on its physical interaction with the 5-HT 6 R. Finally, the constitutive activity of the receptor was also required, as shown by the lack of effect of GPRIN1 in cells co-transfected with the W281A mutant $5-\mathrm{HT}_{6} \mathrm{R}$, which exhibits reduced constitutive activity compared to that of the wild-type receptor (Fig. 3, A and B). This latter result prompted us to explore whether the length of neurites in NG108-15 cells correlated with the abundance of cAMP; thus, we plotted the neurite length of cells as a function of the extent of $5-\mathrm{HT}_{6} \mathrm{R}$ constitutive activity. As expected, there was no correlation between these two factors in cells 24 hours after transfection, whereas 48 hours after transfection, neurite length positively correlated with the extent of constitutive activity of the 5- $\mathrm{HT}_{6} \mathrm{R}$ (Fig. 3C). Further supporting the link between neurite growth, branching, and cAMP production resulting from the constitutive activity of the 5-HT 6 R, neurite length and branching in NG108-15 cells co-expressing GPRIN1 with the mutant $5-\mathrm{HT}_{6} \mathrm{R}$ incapable of activating $\mathrm{G}$ proteins were reduced compared to those in cells coexpressing GPRIN1 with the wild-type receptor (Fig. 3, D and E). Moreover, treating cells coexpressing the wild-type receptor with the $5-\mathrm{HT}_{6} \mathrm{R}$ antagonist SB271046, the membranepermeable cAMP analog RPcAMP, or KT5720 [both of which are inhibitors of cAMPdependent protein kinase (PKA)]also prevented GPRIN1-dependent neurite growth and branching (Fig. 3, D and E), whereas none of these treatments affected neurite architecture in cells expressing the receptor alone. This finding suggests that neurite elongation and branching depend on the activation of PKA stimulated by agonist-independent, 5- $\mathrm{HT}_{6} \mathrm{R}$-dependent cAMP production, which itself requires the physical interaction of GPRIN1 with the receptor. Consistent with our previous study (20), there was no effect of the G protein coupling-defective 
triple receptor mutant or of treatment with RPcAMP on neurite length 24 hours after transfection (fig. S5).

\section{The GPRIN1-5-HT 6 R interaction stimulates neurite elongation and branching in neurons}

We next sought to determine whether the interaction between the native 5-HT6 $\mathrm{R}$ and GPRIN1 likewise promoted neurite elongation and branching in primary cultured neurons. We performed these experiments on striatal neurons, which express large amounts of $5-\mathrm{HT}_{6} \mathrm{R}$ density as well as GPRIN1 (Fig. 4). We first infected striatal neurons with lentiviruses encoding two different shRNAs directed against GPRIN1. Both shRNAs led to a nearly total loss of GPRIN1 protein detection by Western blotting (Fig. 4A). Furthermore, knocking down GPRIN1 statistically significantly decreased both neurite length and the complexity of mature striatal neurons (Fig. 4B), as assessed by Sholl analysis on neurons grown for 13 days in vitro (DIV), reminiscent of what was observed in transfected NG108-15 cells. We next exposed striatal neurons to the TATCt320-342 peptide to disrupt the interaction between GPRIN1 and 5-HT ${ }_{6} \mathrm{R}$. This treatment resulted in a marked decrease in neurite length and complexity as compared with neurons treated with a control TAT peptide (Fig. 4C), suggesting that the interaction between endogenous GPRIN1 and $5 \mathrm{HT}_{6} \mathrm{R}$ is necessary to promote neurite growth and branching in striatal neurons. We then compared, from DIV 1 to DIV 4, the neurite length of neurons treated with either the TAT-Ct320-342 peptide or the control TAT peptide. We found a statistically significant reduction in neurite length as early as DIV 2 in neurons exposed to the TAT-Ct320-342 peptide, and this reduction was further enhanced at DIVs 3 and 4 (fig. S6A). Finally, reminiscent of the observations made in NG108-15 cells, neurons treated with RPcAMP also showed a marked decrease in neurite length measured at DIV 4 (fig. S6B). 


\section{Discussion}

Studies have demonstrated that the $5-\mathrm{HT}_{6} \mathrm{R}$ plays crucial roles in both the correct migration and positioning of neurons, as well as in the initiation of neurite growth $(19,20,43)$. These effects, which are mostly independent of the canonical Gs-cAMP pathway, prompted the use of unbiased interactomic studies to identify previously uncharacterized signaling proteins recruited by the receptor and alternative signaling pathways underlying its control of neuro-developmental processes. These studies revealed that $\mathrm{Cdk} 5$ binds to the $\mathrm{C}$-terminal domain of the receptor to promote neurite growth initiation through an agonist-independent mechanism involving the phosphorylation of $\mathrm{Ser}^{350}$ in the receptor, which in turn leads to activation of the small GTPase Cdc42 (Fig. 5) (20). Here, we showed that the 5- $\mathrm{HT}_{6} \mathrm{R}$ C-terminal domain also recruited GPRIN1, a Cdk5 substrate initially identified in a cDNA bank screen designed to find previously uncharacterized partners of $\mathrm{G} \alpha$ subunits $(30,44)$. Two other variants (GPRIN2 and GPRIN3) have been described, but only GPRIN1 was identified in the 5-HT 6 R interactome. GPRIN1 is mainly found in the central nervous system, where it is expressed by neurons but not glial cells. Its expression is high during embryonic development, with a peak at E16.5. It is still found in the adult brain, but only in the hippocampus, ventral striatum, and some cortical regions (34), which greatly overlaps with the expression pattern of the $5-\mathrm{HT}_{6} \mathrm{R}$. Corroborating these observations, we found that the receptor forms a complex with GPRIN1 in mouse brain at the neonatal stage, a critical period for neuronal differentiation and wiring of neuronal networks (45). At that stage of neural development, receptors are found not only in the primary cilium, as previously described $(36,39,46)$, but also in the soma of neurons, where they are mainly detected at the plasma 
membrane. However, we did not detect GPRIN1 in primary cilia, suggesting that only the receptor pool found outside the cilium is engaged in complexes with GPRIN1.

The GPRIN1 association with the 5- $\mathrm{HT}_{6} \mathrm{R}$, which occurred in absence of agonist, was reduced in cells treated with the 5- $\mathrm{HT}_{6} \mathrm{R}$ antagonist SB271046, which acted as an inverse agonist toward receptor-stimulated Gs-cAMP signaling (Fig 2A). These results suggest that the 5-HT ${ }_{6} \mathrm{R}-$ GPRIN1 interaction is dynamically regulated by the conformational state of the receptor and that a specific receptor conformation in the absence of ligand is favorable for GPRIN1 recruitment. Consistent with this hypothesis, mutating a tryptophan residue essential for $5-\mathrm{HT}_{6} \mathrm{R}$ constitutive activity to an alanine reduced the interaction between the receptor and GPRIN1.

GPRIN1 not only associated with the $5-\mathrm{HT}_{6} \mathrm{R}$ in its active conformation, but it also enhanced the constitutive activity of the receptor leading to Gs signaling (Fig 1G, Fig 2A, B) . Furthermore, we showed that GPRIN1 promoted the recruitment of Gas protein by 5-HT 6 R (Fig 2E). Previous studies showed that GPRIN1 preferentially interacts with activated G $\alpha$ proteins of the Gi/o subfamily (35). Assuming that GPRIN1 likewise associates with activated Gos, we hypothesize that GPRIN1 favors the recruitment of $\mathrm{G} \alpha_{\mathrm{s}}$ by active receptor conformations, resulting in the formation of a ternary complex comprising 5-HT 6 R, GPRIN1, and active Gas, thus promoting receptor constitutive activity. Alternatively, the association of GPRIN1 with the 5-HT $\mathrm{R}_{\text {might }}$ induce a conformational change in the receptor toward a more active state exhibiting a higher level of constitutive activity through Gs signaling. 
Together, our current and previous findings (20) demonstrate a high level of 5- $\mathrm{HT}_{6} \mathrm{R}$ constitutive activity toward both canonical Gs signaling and G protein-independent signaling, which depends on allosteric modulations by interacting proteins. To our knowledge, these data provide one of the few examples of the modulation of the constitutive activity of a GPCR by GPCR-interacting proteins (GIPs). Other examples are the constitutive activity of type I metabotropic glutamate receptors (mGluRs), which can be modulated by Homer proteins, and the constitutive activity of the Ghrelin receptor GHSR1a, which can be regulated by the Melanocortin Receptor Accessory Protein Suunit 2 (MRAP2) $(47,48)$. However, in contrast with our current findings, the association of Homer 3 with the C-terminal domain of mGluR1 or mGluR5, prevents rather than promotes the constitutive activity of either receptor.. whereas the expression of the short, inducible form of Homer (Homer1a) results, indirectly through the disruption of mGluR1- or mGluR5-Homer3 complexes, in the enhanced constitutive activity of mGluR1 or 5. In the case of the GHSR1a receptor, the interaction with MRAP2 results in biaised signaling, enhancing the ghrelin-induced receptor's signaling through $\mathrm{Gq}$, while blocking both its constitutive activity and the recruitment of the $\beta$-arrestin pathways. Our data also suggest that constitutive $5-\mathrm{HT}_{6} \mathrm{R}$ activation can result from different mechanisms depending on the nature of the associated GIP: agonist-independent engagement of $\mathrm{Cdk} 5-\mathrm{Cdc} 42$ signaling depends on receptor phosphorylation at $\operatorname{Ser}^{350}$ by receptor-associated $\mathrm{Cdk} 5$, whereas the activation of Gs signaling by GPRIN1 might result from an enhanced recruitment of activated $\mathrm{G}_{\mathrm{s}}$ or a switch to a more active conformational state of the receptor.

The interactions of $5-\mathrm{HT}_{6} \mathrm{R}$ with $\mathrm{Cdk} 5$ and GPRIN1 seem to occur sequentially to facilitate a fine temporal regulation of key neuro-developmental processes (Fig. 5). Previous studies showed 
that the agonist-independent activation of $\mathrm{Cdk} 5$ by $5-\mathrm{HT}_{6} \mathrm{R}$ early during brain development is essential for the normal positioning of cortical neurons, indicating a fine control of the migration process $(19,43)$. Beyond migration, the association of $5-\mathrm{HT}_{6} \mathrm{R}$ with $\mathrm{Cdk} 5$ also promoted the initiation of neurite growth (20), which is consistent with previous studies performed in PC12 cells, for which the initiation of neurite growth is cAMP-independent (49). At a later stage of neuronal differentiation, the $5-\mathrm{HT}_{6} \mathrm{R}$ might associate with GPRIN1 to induce neurite elongation and branching. This sequential association of $5-\mathrm{HT}_{6} \mathrm{R}$ with $\mathrm{Cdk} 5$ and GPRIN1, initially established in transfected NG108-15 cells, likely occurs between native proteins in primary neurons. Inhibiting agonist-independent activation of $\mathrm{Cdk} 5 / \mathrm{Cdc} 42$ signaling induced by the $5-$ $\mathrm{HT}_{6} \mathrm{R}$ prevented the initiation of neurite growth measured during the first 24 hours after neuron seeding, whereas knockdown of GPRIN1 or disruption of the 5-HT 6 R-GPRIN1 interaction at later stage of neuronal differentiation (between 2 and 13 days after plating) prevented further neurite elongation and branching. These findings provide an example of functionally relevant dynamic interactions between a GPCR and several GIPs. The cellular mechanisms underlying the sequential interaction of $5-\mathrm{HT}_{6} \mathrm{R}$ with $\mathrm{Cdk} 5$ and GPRIN1 remain to be elucidated. As previously mentioned, Cdk5-mediated initiation of neurite growth depends on the phosphorylation of the $5-\mathrm{HT}_{6} \mathrm{R}$ on $\mathrm{Ser}^{350}$ by associated $\mathrm{Cdk} 5$. We also identified in the $5-\mathrm{HT}_{6} \mathrm{R}$ interactome the protein phosphatase PP2A, which dephosphorylates Cdk5 targets (50). Because PKA can phosphorylate and activate PP2A (51), we hypothesize that constitutively active 5$\mathrm{HT}_{6} \mathrm{R}$ might promote the activation of PP2A through PKA, leading to the dephosphorylation of $\mathrm{Ser}^{350}$ and the release of Cdk5, thus facilitating interaction with GPRIN1. The 5-HT ${ }_{6} \mathrm{R}$ might also interact with either Cdk5 or GPRIN1 depending on to their respective subcellular localization. Because both $5-\mathrm{HT}_{6} \mathrm{R}$ and Cdk5 activation increase cilial length, one can speculate that the 
formation of $5-\mathrm{HT}_{6} \mathrm{R}-\mathrm{Cdk} 5$ complexes occurs in the primary cilium or cellular compartments involved in primary cilium morphogenesis (for example, the distal centriole appendages), whereas GPRIN1 associates with receptors located in the soma of neurons.

A viable GPRIN1 knockout mouse (KO) model has been described. Cultured neurons from GPRIN1 KO mice show reduced firing activity compared with neurons from wild-type mice, and adult GPRIN1 KO mice display altered learning performance (52), a phenotype possibly reflecting defects in neurite growth and early neuronal network shaping. Although initial studies showed the ability of GPRIN1 bound to activated Gai/o proteins to promote neurite growth through the activation of $\operatorname{Cdc} 42(33,35)$, our data together with previously published results suggest that its neurite growth-promoting effects tightly depend on its interaction with membrane receptors (31-33). Only the co-expression of GPRIN1 and 5-HT 6 R induced a substantial effect upon neurite elongation and branching in NG108-15 cells, whereas expression of GPRIN1 alone only induced a marginal effect upon neurite growth. Similarly, the association of GPRIN1 with the $\mu$-opioid receptor (MOR) potentiates receptor-mediated neurite growth by targeting MOR tethered with activated Gai to lipid rafts (31), whereas the interaction of GPRIN1 with the $\alpha 7$ nicotinic receptor targets the receptor to growth cones and increase its plasma membrane localization, which results in longer and more complex neurites (31). The signaling mechanisms underlying neurite growth under the control of GPRIN1 might also depend on the nature of the receptor with which GPRIN1 is associated. Whereas neurite growth under the control of the $\alpha 7$-GPRIN1 complex seems to involve a $\mathrm{Ca}^{2+} / \mathrm{CaM}$-kinase II/phosphatase $2 \mathrm{~B}$ pathway (32), the 5-HT 6 R-GPRIN1 complex promotes neurite elongation and branching through a cAMP- and PKA-dependent mechanism. 
In conclusion, our study provides an example of dynamic associations between a GPCR and several of its GIPs to ensure highly coordinated cellular processes such as the growth initiation, extension, and branching of neurites. These findings further highlight the allosteric properties of GPCRs, which can adopt many active and physiologically relevant conformations, some of them being stabilized upon interaction with GIPs in the absence of orthosteric agonists.

\section{Materials and Methods}

\section{Animals}

5-HT6 ${ }^{G F P / G F P}$ knock-in (KI) mice (29) were generated at the Institut Clinique de la Souris (Illkirch-Graffenstaden, France) and were used for GFP-TRAP and immunohistochemistry experiments. Primary cultures of neurons were realized from OF1 mouse embryos originating from Charles River. Procedures were performed in strict compliance with the animal use and care guidelines of Montpellier University (authorization D34-172-4).

\section{Plasmids, chemicals, and antibodies}

The human HA-tagged wild type (WT) 5- $\mathrm{HT}_{6} \mathrm{R}$ construct was previously described $(25,53)$. The human YFP-tagged 5-HT $\mathrm{H}_{6}$ construct was kindly provided by S. Morisset (Centre de Biophysique Moléculaire, Orléans, France). 5- $\mathrm{HT}_{6} \mathrm{R}$ mutants were generated by site-directed mutagenesis and assessed by sequencing. Plasmid encoding human GPRIN1 was purchased from Sigma-Aldrich and the peGFPC1 plasmid was from Clontech. The viral constructs encoding two different shRNAs directed against GPRIN1, subcloned into the pLKO vector, were obtained from Sigma-Aldrich, and pLKO eGFP was obtained from the virus production platform of 
Montpellier (PVM, BioCampus, Montpellier, France). Viral particles were produced by the PVM platform. The agarose-conjugated anti-HA antibody (clone no. HA-7) was purchased from Sigma-Aldrich, GFP-TRAP beads were from Chromotek, the rabbit anti-GPRIN1 antibody was from Proteintech (Ref 13771-1-AP), the rabbit anti-Gas antibody was from Calbiochem (Ref 371732), the rat anti-HA antibody (clone 3F10) was from Roche, the mouse anti-MAP2 antibody (clone [HM2], ref ab11267) was from Abcam, and the mouse anti-Arl13b (clone N295B/66 ref 75-287) was from Antibodies Incorporated. For GFP labelling, we used the chicken polyclonal anti-GFP antibody (A10262, ref 10524234) from Thermo-Fisher Scientific or the rabbit polyclonal anti-GFP antibody (ref PABG1) from Chromotek. WAY181187, SB271046 hydrochloride, KT 5720, and cAMPS-Rp triethylammonium salt were purchased from Tocris Biosciences. Coelenterazine h (used for BRET experiments) was purchased from Nanolight Technology (Ref 50909-86-9). The CAMYEL probe and the derivatized benzyl guanine labelled with europium cryptate (BG-K) or $\mathrm{d} 2$ (BG-d2) as acceptor were provided by the pharmacological screening facility (ARPEGE, BioCampus Montpellier, France). Interfering peptides (>90\% purity) were purchased from Genscript. Peptide sequences were as follows: TAT Ct320-342 peptide: YGRKKRRQRRRPLFMRDFKRALGRFLPCPRCPR; TAT control peptide: GRKKRRQRRRRPCRPCPLFRGLARKFDRMFLP.

\section{Cell culture, transfection, and treatments}

NG108-15 cells were grown in Dulbecco's modified Eagle's medium (DMEM) supplemented with $10 \%$ dialyzed fetal calf serum (FCS), $2 \%$ hypoxanthine/aminopterin/thymidine (Life Technologies), and antibiotics. Cells were transfected in suspension using Lipofectamine 2000 (Life Technologies) with plasmids encoding GFP, WT or mutant HA-5-HT ${ }_{6}$ Rs with or 
without the plasmid encoding GPRIN1. After transfection, cells were maintained in DMEM supplemented with $2 \%$ dialyzed FCS and treated as indicated in the figure legends either 5 or 24 hours after transfection. The cells were used either 24 or 48 hours after transfection for all experiments. Primary cultures of striatal neurons were prepared from E15.5 OF1 mouse embryos. Striata were dissociated by manual trituration and cells were plated onto polyornithine and laminin-coated $12-\mathrm{mm}$ glass coverslips in 24-well plates. Cultures were maintained in Neurobasal medium (Thermo Scientific) supplemented with $10 \mathrm{ml}$ of B27 supplement (Gibco Ref 17504-044), $0.2 \mathrm{mM}$ GlutaMAX, with $0.2 \mathrm{mM}$ glutamine and penicillin (100 $\mathrm{u}) /$ streptomycin $(100 \mu \mathrm{g})$ and kept at $37^{\circ} \mathrm{C}$ in a humidified atmosphere containing $5 \% \mathrm{CO}_{2}$. For branching experiments, neurons were transfected at DIV 1 with cDNA encoding GFP to visualize dendritic trees, treated at DIV 4 as indicated in the figure legends, and fixed at DIV 13.

\section{Immunocytochemistry and morphological analyses}

NG108-15 cells or neurons, grown on coated glass coverslips, were fixed in paraformaldehyde (PFA; 4\% for $10 \mathrm{~min}$ for NG108-15 cells and $2 \%$ for 15 min for neurons). Cells were then successively incubated with primary antibodies (mouse anti-MAP-2, 1:1,000, rabbit anti GPRIN1 1:500, or rat anti-HA, 1:1,000) and with secondary antibodies (Alexa Fluor 488conjugated anti-mouse or Alexa Fluor 594-conjugated anti-rabbit, 1:1,000). For labelling of the $5-\mathrm{HT}_{6} \mathrm{R}$ in cultured neurons, tyramide amplification of the signal given by the rabbit polyclonal antibody $(1: 1,000)$ was performed using the Invitrogen Alexa Fluor 488 Tyramide Superboost kit (ref 15631902) according to the manufacturer' protocol. Coverslips were mounted in Mowiol. Images were captured with an AxioImagerZ1 microscope equipped with epifluorescence (Zeiss), using a $20 \times$ objective. Neurites were detected based on MAP2 staining or GFP expression. 
Neurite length was measured using the NeuronJ plugin of ImageJ software. A minimum of 15 fields of cells originating from three independent cultures was analyzed per condition. Branching was assessed using a semi-automated Sholl analysis with $5-\mu \mathrm{m}$ ring intervals starting at $5 \mu \mathrm{m}$ from the soma (SynD, MatLab). A minimum of 45 cells originating from three independent cultures were analyzed for each condition.

\section{Immunohistochemistry on brain slices}

Mice were rapidly anesthetized with isoflurane and perfused transcardially with $0.1 \mathrm{M}$ phosphate-buffered sodium (PBS, pH 7.5). Brains were then fixed in 4\% PFA diluted in PBS for 24 hours at $4{ }^{\circ} \mathrm{C}$, and thenincubated successively in 10,20 , and $30 \%(\mathrm{w} / \mathrm{vol})$ sucrose diluted in PBS for cryoprotection. Sixteen-micrometer-thick sections were cut with a cryostat (Leica), deposited directly on slides, and stored at $-80^{\circ} \mathrm{C}$ until use. For immunolabeling experiments, sections were thawed at room temperature and rehydrated for 15 min in PBS. Sections were blocked for 2 hours in PBS containing 0.2\% (v/v) Triton X-100, 3\% (w/v) BSA (A2153 SigmaAldrich) and then incubated overnight at room temperature in primary antibody solution containing 1:1000 anti-GFP from Chicken (A10262 Invitrogen) and 1:500 anti-GPRIN1 from Rabbit (13771-1-AP Proteintech) in PBS, 0.2\% Triton X-100, 1\% BSA. Sections were then washed three times for 30 min each in PBS and incubated with Alexa-488-coupled goat antichicken and Cy3-coupled Goat anti-rabbit secondary antibodies (1:1000) for 2 hours at room temperature. Sections were washed three times for 30 min each in PBS, dried, and mounted in DPX mountant (Ref 06522 Sigma-Aldrich). Images were acquired with a Leica SP8 confocal microscope equipped with an oil-immersed 63x objective, with a 2048 x 2048 resolution 
(excitation lasers: 488 and $561 \mathrm{~nm}$; acquisition filters respectively: 500 to $539 \mathrm{~nm}$ and 572 to 617 $\mathrm{nm})$.

\section{Immunoprecipitation experiments}

Whole brains from new-born mice were washed in PBS and homogenized by potterization. The samples were centrifuged at $3000 \mathrm{~g}$ for $10 \mathrm{~min}$ at $4^{\circ} \mathrm{C}$. Pellets were resuspended in solubilization buffer containing 10 mM Tris- $\mathrm{HCl}$ (pH 7.4), $150 \mathrm{mM} \mathrm{NaCl}, 0.5 \mathrm{mM}$ EDTA, 0.4\% Dodecyl Maltoside, $0.5 \%$ Triton X-100, and a protease cocktail inhibitor (Roche). Samples were left to solubilize at $4^{\circ} \mathrm{C}$ for 4 hours and then were centrifuged for $30 \mathrm{~min}$ at $13,000 \mathrm{~g}$ at $4^{\circ} \mathrm{C}$. Protein concentration was measured using a Bicinchoninic Assay (BCA, Sigma) and solubilized proteins were used for GFP-TRAP assays (Chromotek). Transfected NG108-15 cells were lysed in a solubilization buffer containing $20 \mathrm{mM}$ HEPES (pH 7.4), $150 \mathrm{mM} \mathrm{NaCl}, 1 \%$ NP-40, $10 \%$ glycerol, $4 \mathrm{mg} / \mathrm{ml}$ dodecylmaltoside, phosphatase inhibitors $(10 \mathrm{mM} \mathrm{NaF}, 2 \mathrm{mM}$ sodium orthovanadate, $1 \mathrm{mM}$ sodium pyrophosphate, and $50 \mathrm{mM} \beta$-glycerophosphate) and a protease inhibitor cocktail (Roche) for 1 hour at $4^{\circ} \mathrm{C}$. Samples were centrifuged at 15,000g for 15 min at $4^{\circ} \mathrm{C}$, and supernatants containing solubilized proteins were used for immunoprecipitation. Solubilized proteins (1 mg per condition) were incubated either with agarose-conjugated anti-HA antibody or GFP-TRAP beads overnight at $4{ }^{\circ} \mathrm{C}$. The beads were washed five times with lysis buffer for anti-HA beads or with a washing buffer specified by the manufacturer protocol for

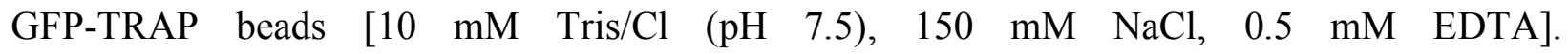
Immunoprecipitated proteins were then eluted in Laemmli sample buffer and analzsed by Western blotting. 


\section{Western blotting analysis}

Proteins were separated on $10 \%$ polyacrylamide gels and then were transferred to Hybond C nitrocellulose membranes (GE Healthcare). Membranes were first incubated with the appropriate primary antibodies (rabbit anti-GPRIN1, 1:500; rabbit anti-Gs $\alpha, 1: 500$; rat antiHA, 1:1,000) and then with horseradish peroxidase (HRP)-conjugated anti-rat or anti-rabbit secondary antibodies (1: 5000, GE Healthcare). Immunoreactivity was detected with an enhanced chemiluminescence method (ECL plus detection reagent, GE Healthcare) and imaged with a Chemidoc system (Biorad). Immunoreactive bands were quantified by densitometry using Image Lab software (Biorad).

\section{BRET experiments}

NG108-15 cells were transfected in white 96-well Microplates (Greiner) with a fixed amount of CDK5-Rluc plasmid and an increasing concentration of 5-HT 6 R-YFP construct (from 0 to 20 ng/well). The BRET signal from each plate was first analyzed 24 hours after the transfection and then again at 48 hours. We collected BRET measurements 2 min after the addition of the luciferase substrate coelenterazine $\mathrm{h}$, at a final concentration of $5 \mu \mathrm{M}$. Luminescence and fluorescence were detected with a Mithras LB 940 Multireader (Berthold), which enables the sequential integration of luminescence signals detected with two filter settings (RLuc filter: 485 $\pm 10 \mathrm{~nm}$; YFP filter: $530 \pm 12 \mathrm{~nm}$ ). Emission signals at $530 \mathrm{~nm}$ were divided by emission signals at $485 \mathrm{~nm}$. The BRET ratio was defined as the difference between the emission ratio obtained with co-transfected RLuc and YFP fusion proteins and that obtained with the RLuc fusion protein alone. The results were expressed in milliBRET units (mBU; with $1 \mathrm{mBU}$ corresponding to the BRET ratio values multiplied by 1000). Total fluorescence and luminescence were used as 
relative measures of total amounts of the YFP- and RLuc-tagged proteins, respectively. BRET signals were plotted as a function of the ratio between total fluorescence and total luminescence ratio.

\section{cAMP measurements}

cAMP measurement was performed in NG108-15 cells transiently expressing 5-HT 6 R using the bioluminescence resonance energy transfer (BRET) sensor for cAMP, CAMYEL (cAMP sensor using YFP-Epac-RLuc) (41). NG108-15 cells were co-transfected in suspension with the 5-HT $\mathrm{R}$ and CAMYEL constructs using Lipofectamine 2000 according to the manufacturer's protocol and plated in white 96-well plates (Greiner) at a density of 80,000 cells per well. Twenty-four hours after transfection, the cells were washed with PBS containing calcium chloride and magnesium chloride (Gibco, Ref 14040-091). Coelanterazine $\mathrm{h}$ was added at a final concentration of $5 \mu \mathrm{M}$. Plates were incubated at room temperature for $5 \mathrm{~min}$ before BRET measurements. BRET was measured using a Mithras LB 940 plate reader. Expression of 5-HT 6 R in NG-108-15 cells induced a decrease in the CAMYEL BRET signal compared to that in cells transfected with an empty vector. This decrease in CAMYEL BRET signal was used as an index of $5-\mathrm{HT}_{6} \mathrm{R}$ constitutive activity through Gs signaling.

\section{Measurement of cell surface 5-HT 6 Ry Tr-FRET}

These experiments were performed as described previously (54). NG 108-15 cells were transfected with plasmid encoding a SNAP-tagged $5-\mathrm{HT}_{6} \mathrm{R}$ with or without plasmid encoding GPRIN1 or were transfected with an empty plasmid. Forty-eight hours after transfection, the cells were plated in a Greiner CellStar 96-well plate (at 50,000 cells per well) and washed with 
PBS supplemented with calcium chloride and magnesium chloride (Gibco, Ref 14040-091). The cells were then labelled with derivatized benzyl guanine (BG-K or BG-d2) for 1 hour at $37^{\circ} \mathrm{C}$ in a humidified atmosphere containing $5 \% \mathrm{CO}_{2}$. After labelling, the cells were washed four times with PBS. The emission signal from the cryptate was recorded at $620 \mathrm{~nm}$ on a time-resolved fluorimeter (RubyStar, BMG Labtechnologies, Champigny-sur-Marne, France) after excitation at $337 \mathrm{~nm}$ by a nitrogen laser and the emission signal from the $\mathrm{d} 2$ was recorded at $682 \mathrm{~nm}$ on an Analyst reader (Molecular Devices) using a $640 \mathrm{~nm}$ excitation. The specific fluorescence signal was determined by subtracting the nonspecific signal in mock-transfected cells from the total fluorescence signal in the cells expressing the SNAP-tagged 5-HT 6 R.

\section{Statistical analysis}

Statistical analyses were performed using Prism4 (GraphPad Software Inc). For two-sample and multiple comparisons (Western blots, cAMP production, and neurite length measurements), the unpaired Student's t-test and one-way ANOVA followed by Newman Keuls Multiple Comparisons test were used, respectively. Two-way ANOVA followed by Bonferroni's multiple comparisons test was used to evaluate significance of Sholl analysis. $P<0.05$ was considered to be statistically significant. Correlation between neurite length and the extent of 5- $\mathrm{HT}_{6} \mathrm{R}$ constitutive activity in NG108-15 cells was evaluated 24 and 48 hours after transfection by linear regression analysis.

\section{Supplementary Materials}

Fig. S1. 5-HT 6 R and GPRIN1 are co-localized at the soma plasma membrane of striatal and cortical neurons but not in primary cilia.

Fig. S2. Inputs for the immunoprecipitation experiments presented in Figures 1 and 2.

Fig. S3. Impact of the phosphorylation of 5- $\mathrm{HT}_{6} \mathrm{R} \mathrm{Ser}{ }^{350}$ upon its interaction with GPRIN1.

Fig. S4. Impact of GPRIN1 co-expression with the $5-\mathrm{HT}_{6} \mathrm{R}$ on receptor cell surface expression in 
NG108-15 cells.

Fig. S5. GPRIN1 selectively affects the late stage of neurite growth in NG108-15 cells.

Fig. S6. Interaction between endogenous 5-HT 6 R and GPRIN1 promotes neurite extension through a cAMP-dependent mechanism in striatal neurons.

References and Notes

1. S. K. Shenoy, R. J. Lefkowitz, Seven-transmembrane receptor signaling through beta-arrestin. Science's STKE : signal transduction knowledge environment 2005, cm10 (2005); published online EpubNov 1 (10.1126/stke.2005/308/cm10).

2. J. Bockaert, L. Fagni, A. Dumuis, P. Marin, GPCR interacting proteins (GIP). Pharmacol Ther 103, 203-221 (2004); published online EpubSep (S01637258(04)00100-7 [pii]

10.1016/j.pharmthera.2004.06.004).

3. J. Bockaert, J. Perroy, C. Becamel, P. Marin, L. Fagni, GPCR interacting proteins (GIPs) in the nervous system: Roles in physiology and pathologies. Annu Rev Pharmacol Toxicol 50, 89-109 (2010)10.1146/annurev.pharmtox.010909.105705).

4. A. C. Magalhaes, H. Dunn, S. S. Ferguson, Regulation of GPCR activity, trafficking and localization by GPCR-interacting proteins. Br J Pharmacol 165, 1717-1736 (2012); published online EpubMar (10.1111/j.1476-5381.2011.01552.x).

5. S. L. Ritter, R. A. Hall, Fine-tuning of GPCR activity by receptor-interacting proteins. Nature reviews. Molecular cell biology 10, 819-830 (2009); published online EpubDec (10.1038/nrm2803).

6. J. Bockaert, P. Marin, A. Dumuis, L. Fagni, The 'magic tail' of G protein-coupled receptors: an anchorage for functional protein networks. FEBS Lett 546, 65-72 (2003); published online EpubJul 3 (S0014579303004538 [pii]).

7. J. Bockaert, G. Roussignol, C. Becamel, S. Gavarini, L. Joubert, A. Dumuis, L. Fagni, P. Marin, GPCR-interacting proteins (GIPs): nature and functions. Biochem Soc Trans 32, 851-855 (2004); published online EpubNov (BST0320851 [pii]

10.1042/BST0320851).

8. C. Gerard, M. P. Martres, K. Lefevre, M. C. Miquel, D. Verge, L. Lanfumey, E. Doucet, M. Hamon, S. el Mestikawy, Immuno-localization of serotonin 5-HT6 receptor-like material in the rat central nervous system. Brain Res 746, 207-219 (1997); published online EpubJan 23 (S0006-8993(96)01224-3 [pii]).

9. L. Helboe, J. Egebjerg, I. E. de Jong, Distribution of serotonin receptor 5-HT6 mRNA in rat neuronal subpopulations: A double in situ hybridization study. 
Neuroscience 310, 442-454 (2015); published online EpubDec 3 (10.1016/j.neuroscience.2015.09.064).

10. A. M. Kinsey, A. Wainwright, R. Heavens, D. J. Sirinathsinghji, K. R. Oliver, Distribution of 5-ht(5A), 5-ht(5B), 5-ht(6) and 5-HT(7) receptor mRNAs in the rat brain. Brain research. Molecular brain research 88, 194-198 (2001); published online EpubMar 31 (

11. F. J. Monsma, Jr., Y. Shen, R. P. Ward, M. W. Hamblin, D. R. Sibley, Cloning and expression of a novel serotonin receptor with high affinity for tricyclic psychotropic drugs. Mol Pharmacol 43, 320-327 (1993); published online EpubMar (

12. M. Ruat, E. Traiffort, J. M. Arrang, J. Tardivel-Lacombe, J. Diaz, R. Leurs, J. C. Schwartz, A novel rat serotonin (5-HT6) receptor: molecular cloning, localization and stimulation of cAMP accumulation. Biochem Biophys Res Commun 193, 268276 (1993); published online EpubMay 28 (

13. X. Codony, J. M. Vela, M. J. Ramirez, 5-HT(6) receptor and cognition. Current opinion in pharmacology 11, 94-100 (2011); published online EpubFeb (10.1016/j.coph.2011.01.004).

14. G. Maher-Edwards, R. Dixon, J. Hunter, M. Gold, G. Hopton, G. Jacobs, J. Hunter, P. Williams, SB-742457 and donepezil in Alzheimer disease: a randomized, placebo-controlled study. International journal of geriatric psychiatry 26, 536-544 (2011); published online EpubMay (10.1002/gps.2562).

15. G. Maher-Edwards, C. Watson, J. Ascher, C. Barnett, D. Boswell, J. Davies, M. Fernandez, A. Kurz, O. Zanetti, B. Safirstein, J. P. Schronen, M. Zvartau-Hind, M. Gold, Two randomized controlled trials of SB742457 in mild-to-moderate Alzheimer's disease. Alzheimer's \& dementia 1, 23-36 (2015); published online EpubJun (10.1016/j.trci.2015.04.001).

16. G. Maher-Edwards, M. Zvartau-Hind, A. J. Hunter, M. Gold, G. Hopton, G. Jacobs, M. Davy, P. Williams, Double-blind, controlled phase II study of a 5-HT6 receptor antagonist, SB-742457, in Alzheimer's disease. Curr Alzheimer Res 7, 374-385 (2010); published online EpubAug (

17. D. Wilkinson, K. Windfeld, E. Colding-Jørgensen, Safety and efficacy of idalopirdine, a 5-HT6 receptor antagonist, in patients with moderate Alzheimer's disease (LADDER): a randomised, double-blind, placebo-controlled phase 2 trial. The Lancet Neurology 13, 1092-1099 10.1016/S1474-4422(14)70198-X). 
18. A. Atri, L. Frolich, C. Ballard, P. N. Tariot, J. L. Molinuevo, N. Boneva, K. Windfeld, L. L. Raket, J. L. Cummings, Effect of Idalopirdine as Adjunct to Cholinesterase Inhibitors on Change in Cognition in Patients With Alzheimer Disease: Three Randomized Clinical Trials. JAMA 319, 130-142 (2018); published online EpubJan 9 (10.1001/jama.2017.20373).

19. M. Jacobshagen, M. Niquille, S. Chaumont-Dubel, P. Marin, A. Dayer, The serotonin 6 receptor controls neuronal migration during corticogenesis via a ligand-independent Cdk5-dependent mechanism. Development 141, 3370-3377 (2014); published online EpubSep (10.1242/dev.108043).

20. F. Duhr, P. Deleris, F. Raynaud, M. Seveno, S. Morisset-Lopez, C. Mannoury la Cour, M. J. Millan, J. Bockaert, P. Marin, S. Chaumont-Dubel, Cdk5 induces constitutive activation of 5-HT6 receptors to promote neurite growth. Nature chemical biology 10, 590-597 (2014); published online EpubJul (10.1038/nchembio.1547).

21. O. Riccio, G. Potter, C. Walzer, P. Vallet, G. Szabo, L. Vutskits, J. Z. Kiss, A. G. Dayer, Excess of serotonin affects embryonic interneuron migration through activation of the serotonin receptor 6. Mol Psychiatry 14, 280-290 (2009); published online EpubMar (mp200889 [pii]

10.1038/mp.2008.89).

22. C. M. Ha, D. Park, Y. Kim, M. Na, S. Panda, S. Won, H. Kim, H. Ryu, Z. Y. Park, M. M. Rasenick, S. Chang, SNX14 is a bifunctional negative regulator for neuronal 5-HT6 receptor signaling. J Cell Sci 128, 1848-1861 (2015); published online EpubMay 1 (10.1242/jcs.169581).

23. S. H. Kim, D. H. Kim, K. H. Lee, S. K. Im, E. M. Hur, K. C. Chung, H. Rhim, Direct interaction and functional coupling between human 5-HT6 receptor and the light chain 1 subunit of the microtubule-associated protein 1B (MAP1B-LC1). PLoS One 9, e91402 (2014)10.1371/journal.pone.0091402).

24. S. H. Kim, M. Seo, H. Hwang, D. M. Moon, G. H. Son, K. Kim, H. Rhim, Physical and Functional Interaction between 5-HT6 Receptor and Nova-1. Experimental neurobiology 28, 17-29 (2019); published online EpubFeb (10.5607/en.2019.28.1.17).

25. J. Meffre, S. Chaumont-Dubel, C. Mannoury la Cour, F. Loiseau, D. J. Watson, A. Dekeyne, M. Seveno, J. M. Rivet, F. Gaven, P. Deleris, D. Herve, K. C. Fone, J. Bockaert, M. J. Millan, P. Marin, 5-HT(6) receptor recruitment of mTOR as a 
mechanism for perturbed cognition in schizophrenia. EMBO Mol Med 4, 1043-1056 (2012); published online EpubOct (10.1002/emmm.201201410).

26. H. M. Yun, J. H. Baik, I. Kang, C. Jin, H. Rhim, Physical interaction of Jab1 with human serotonin 6 G-protein-coupled receptor and their possible roles in cell survival. J Biol Chem 285, 10016-10029 (2010); published online EpubMar 26 (M109.068759 [pii]

10.1074/jbc.M109.068759).

27. H. M. Yun, S. Kim, H. J. Kim, E. Kostenis, J. I. Kim, J. Y. Seong, J. H. Baik, H. Rhim, The novel cellular mechanism of human 5-HT6 receptor through an interaction with Fyn. J Biol Chem 282, 5496-5505 (2007); published online EpubFeb 23 (M606215200 [pii]

10.1074/jbc.M606215200).

28. R. Kohen, L. A. Fashingbauer, D. E. Heidmann, C. R. Guthrie, M. W. Hamblin, Cloning of the mouse $5-\mathrm{HT} 6$ serotonin receptor and mutagenesis studies of the third cytoplasmic loop. Brain research. Molecular brain research 90, 110-117 (2001); published online EpubJun 20 (

29. W. Deraredj Nadim, S. Chaumont-Dubel, F. Madouri, L. Cobret, M. L. De Tauzia, P. Zajdel, H. Benedetti, P. Marin, S. Morisset-Lopez, Physical interaction between neurofibromin and serotonin 5-HT6 receptor promotes receptor constitutive activity. Proc Natl Acad Sci U S A 113, 12310-12315 (2016); published online EpubOct 25 (10.1073/pnas.1600914113).

30. N. lida, T. Kozasa, Identification and biochemical analysis of GRIN1 and GRIN2. Methods Enzymol 390, 475-483 (2004)10.1016/S0076-6879(04)90029-8).

31. X. Ge, Y. Qiu, H. H. Loh, P. Y. Law, GRIN1 regulates micro-opioid receptor activities by tethering the receptor and $\mathrm{G}$ protein in the lipid raft. $J$ Biol Chem 284, 36521-36534 (2009); published online EpubDec 25 (10.1074/jbc.M109.024109).

32. J. C. Nordman, N. Kabbani, An interaction between alpha7 nicotinic receptors and a G-protein pathway complex regulates neurite growth in neural cells. $J$ Cell Sci 125, 5502-5513 (2012); published online EpubNov 15 (10.1242/jcs.110379).

33. J. C. Nordman, W. S. Phillips, N. Kodama, S. G. Clark, C. A. Del Negro, N. Kabbani, Axon targeting of the alpha 7 nicotinic receptor in developing hippocampal neurons by Gprin1 regulates growth. J Neurochem 129, 649-662 (2014); published online EpubMay (10.1111/jnc.12641). 
34. I. Masuho, Y. Mototani, Y. Sahara, J. Asami, S. Nakamura, T. Kozasa, T. Inoue, Dynamic expression patterns of $G$ protein-regulated inducer of neurite outgrowth 1 (GRIN1) and its colocalization with Galphao implicate significant roles of Galphao-GRIN1 signaling in nervous system. Developmental dynamics : an official publication of the American Association of Anatomists 237, 2415-2429 (2008); published online EpubSep (10.1002/dvdy.21686).

35. H. Nakata, T. Kozasa, Functional characterization of Galphao signaling through G protein-regulated inducer of neurite outgrowth 1. Mol Pharmacol 67, 695-702 (2005); published online EpubMar (10.1124/mol.104.003913).

36. M. Brodsky, A. J. Lesiak, A. Croicu, N. Cohenca, J. M. Sullivan, J. F. Neumaier, 5HT6 receptor blockade regulates primary cilia morphology in striatal neurons. Brain Res 1660, 10-19 (2017); published online EpubApr 1 (10.1016/j.brainres.2017.01.010).

37. M. Hamon, E. Doucet, K. Lefevre, M. C. Miquel, L. Lanfumey, R. Insausti, D. Frechilla, J. Del Rio, D. Verge, Antibodies and antisense oligonucleotide for probing the distribution and putative functions of central 5-HT6 receptors. Neuropsychopharmacology 21, 68S-76S (1999); published online EpubAug (10.1016/S0893-133X(99)00044-5

S0893133X99000445 [pii]).

38. L. Hu, B. Wang, Y. Zhang, Serotonin 5-HT6 receptors affect cognition in a mouse model of Alzheimer's disease by regulating cilia function. Alzheimer's research \& therapy 9, 76 (2017); published online EpubSep 20 (10.1186/s13195-017-0304-4).

39. A. J. Lesiak, M. Brodsky, N. Cohenca, A. G. Croicu, J. F. Neumaier, Restoration of Physiological Expression of 5-HT6 Receptor into the Primary Cilia of Null Mutant Neurons Lengthens Both Primary Cilia and Dendrites. Mol Pharmacol 94, 731-742 (2018); published online EpubJul (10.1124/mol.117.111583).

40. J. Zhang, C. P. Shen, J. C. Xiao, T. J. Lanza, L. S. Lin, B. E. Francis, T. M. Fong, R. Z. Chen, Effects of mutations at conserved TM II residues on ligand binding and activation of mouse 5-HT6 receptor. Eur J Pharmacol 534, 77-82 (2006); published online EpubMar 18 (

41. L. I. Jiang, J. Collins, R. Davis, K. M. Lin, D. DeCamp, T. Roach, R. Hsueh, R. A. Rebres, E. M. Ross, R. Taussig, I. Fraser, P. C. Sternweis, Use of a cAMP BRET sensor to characterize a novel regulation of CAMP by the sphingosine 1- 
phosphate/G13 pathway. J Biol Chem 282, 10576-10584 (2007); published online EpubApr 6 (10.1074/jbc.M609695200).

42. L. P. Pellissier, J. Sallander, M. Campillo, F. Gaven, E. Queffeulou, M. Pillot, A. Dumuis, S. Claeysen, J. Bockaert, L. Pardo, Conformational toggle switches implicated in basal constitutive and agonist-induced activated states of 5hydroxytryptamine-4 receptors. Mol Pharmacol 75, 982-990 (2009); published online EpubApr (10.1124/mol.108.053686).

43. A. G. Dayer, M. Jacobshagen, S. Chaumont-Dubel, P. Marin, 5-HT Receptor: A New Player Controlling the Development of Neural Circuits. ACS chemical neuroscience, (2015); published online EpubJan 28 (10.1021/cn500326z).

44. L. T. Chen, A. G. Gilman, T. Kozasa, A candidate target for G protein action in brain. J Biol Chem 274, 26931-26938 (1999); published online EpubSep 17 (

45. B. D. Semple, K. Blomgren, K. Gimlin, D. M. Ferriero, L. J. Noble-Haeusslein, Brain development in rodents and humans: Identifying benchmarks of maturation and vulnerability to injury across species. Progress in neurobiology 106-107, 1-16 (2013); published online EpubJul-Aug (10.1016/j.pneurobio.2013.04.001).

46. N. F. Berbari, A. D. Johnson, J. S. Lewis, C. C. Askwith, K. Mykytyn, Identification of ciliary localization sequences within the third intracellular loop of $G$ proteincoupled receptors. Molecular biology of the cell 19, 1540-1547 (2008); published online EpubApr (10.1091/mbc.E07-09-0942).

47. F. Ango, L. Prezeau, T. Muller, J. C. Tu, B. Xiao, P. F. Worley, J. P. Pin, J. Bockaert, L. Fagni, Agonist-independent activation of metabotropic glutamate receptors by the intracellular protein Homer. Nature 411, 962-965 (2001); published online EpubJun 21 (10.1038/35082096).

48. A. A. J. Rouault, L. K. Rosselli-Murai, C. C. Hernandez, L. E. Gimenez, G. G. Tall, J. A. Sebag, The GPCR accessory protein MRAP2 regulates both biased signaling and constitutive activity of the ghrelin receptor GHSR1a. Science signaling 13, (2020); published online EpubJan 7 (10.1126/scisignal.aax4569).

49. J. Z. Yu, R. H. Dave, J. A. Allen, T. Sarma, M. M. Rasenick, Cytosolic G\{alpha\}s acts as an intracellular messenger to increase microtubule dynamics and promote neurite outgrowth. J Biol Chem 284, 10462-10472 (2009); published online EpubApr 17 (10.1074/jbc.M809166200).

50. Veeranna, K. T. Shetty, W. T. Link, H. Jaffe, J. Wang, H. C. Pant, Neuronal cyclindependent kinase-5 phosphorylation sites in neurofilament protein (NF-H) are 
dephosphorylated by protein phosphatase 2A. J Neurochem 64, 2681-2690 (1995); published online EpubJun (

51. J. H. Ahn, T. McAvoy, S. V. Rakhilin, A. Nishi, P. Greengard, A. C. Nairn, Protein kinase $A$ activates protein phosphatase $2 \mathrm{~A}$ by phosphorylation of the B56delta subunit. Proc Natl Acad Sci U S A 104, 2979-2984 (2007); published online EpubFeb 20 (10.1073/pnas.0611532104).

52. C. Savoia, Pujol J, Vaucher A, De Marchi U, Rieker C, Heikkilä E, Nunez Galindo A, Dayon L, Dioum E, GPRIN1 modulates neuronal signal transduction and affects mouse-learning behavior. bioRxiv, (2018) https://doi.org/10.1101/291377).

53. S. Claeysen, P. Faye, M. Sebben, S. Lemaire, J. Bockaert, A. Dumuis, Cloning and expression of human 5-HT4S receptors. Effect of receptor density on their coupling to adenylyl cyclase. Neuroreport 8, 3189-3196 (1997); published online EpubOct 20 (

54. D. Maurel, L. Comps-Agrar, C. Brock, M. L. Rives, E. Bourrier, M. A. Ayoub, H. Bazin, N. Tinel, T. Durroux, L. Prezeau, E. Trinquet, J. P. Pin, Cell-surface proteinprotein interaction analysis with time-resolved FRET and snap-tag technologies: application to GPCR oligomerization. Nature methods 5, 561-567 (2008); published online EpubJun (10.1038/nmeth.1213).

Acknowledgments: Mass spectrometry analyses were performed using the facilities of the Functional Proteomic Platform of Montpellier Languedoc-Roussillon. Confocal microscopy was performed using the facilities of Montpellier Imaging Resources (MRI) platform. The BRET and FRET experiments were performed using the ARPEGE (Pharmacology, Screening, Interactome) platform facility (IGF, Montpellier, France). We thank Quentin Durix and Elodie Belan from the iexplore animal facility, RAM, Biocampus. We also thank A. Monteil and C. Lemmers from the virus production facility, PVM, (Biocampus Montpellier, CNRS UMS 3426) for the production of viral particles. We thank M. Asari for her help with iconography. We also thank Dr Séverine Morisset for the gift of the 5-HT6R- GFP plasmid. Funding: This work was supported by grants from the ANR [Sero6Cognet (ANR-11-BSV4-008-01) and Sero6Dev (ANR-17-CE16-0010$01)$ ], CNRS, INSERM, and the University of Montpellier and la Région Occitanie. We also thank the Foundation for Medical Research (FRM). Author contributions: P.M., J.B., and S.C.D. designed experiments; M.S. performed mass spectrometry experiments; C.P. and L.R. studied neurite growth and branching in culture; C.P. performed BRET, FRET, and biochemistry experiments; V.D. performed immunohistochemistry experiments; S.C.D. performed BRET and pharmacology experiments; and P.M., J.B., and S.C.D. wrote the manuscript. Competing interests: The authors declare that they have no competing interests. Data and materials availability: All data needed to evaluate the conclusions in the paper are present in the paper or the Supplementary Materials. 
Fig. 1. Association of the 5-HT 6 Rith GPRIN1 requires both the receptor C-terminal domain and Gs protein. (A) A simple interaction file was designed and imported in Cytoscape (v 2.8.1) to graphically show the interactions between the 5- $\mathrm{HT}_{6} \mathrm{R}$ and a network of proteins involved in the control of cytoskeletal dynamics. GPRIN1 is highlighted in pink. (B) Coimmunoprecipitation of the 5- $\mathrm{HT}_{6} \mathrm{R}$ and GPRIN1 from the brain extracts of new-born 5-HT 6 RGFP KI mice. Western blots are representative of three independent experiments. (C) $5-\mathrm{HT}_{6} \mathrm{R}$ immunostaining (assessed with an anti-GFP antibody, cyan) and GPRIN1 immunostaining (magenta) in the striatum from neonatal $5-\mathrm{HT}_{6} \mathrm{R}-\mathrm{GFP}$ KI mice. Scale bar, $5 \mu \mathrm{m}$. Right: Line graphs generated in Image $\mathrm{J}$ using the lines represented on the merged image highlight the colocalization of both proteins at the plasma membrane in cell bodies (top), but not primary cilia (bottom). (D to H) NG108-15 cells were co-transfected with constructs encoding HA-tagged WT 5-HT 6 R or the indicated 5- $\mathrm{HT}_{6} \mathrm{R}$ mutants in the absence or presence of a GPRIN1 construct. (F and G) Cells were lysed 48 hours after transfection. (H) Cells were treated with $1 \mu \mathrm{M}$ SB271046 (SB, which was added 24 hours after transfection and incubated for 24 hours) and the cells were lysed 48 hours after transfection. 5- $\mathrm{HT}_{6} \mathrm{R}$ proteins were immunoprecipitated with agarose-conjugated anti-HA antibodies. The presence of GPRIN1 (D, F, G, H) or Cdk5 (E) in the immunoprecipitated samples was assessed by Western blotting analysis. Western blots are representative of three independent experiments. Bar charts show densitometric analysis of the indicated bands and are means \pm SEM of three experiments. $* * P<0.01, * * * P<0.001$, and $* * * * P<0.0001$ compared to cells expressing the $5-\mathrm{HT}_{6} \mathrm{R}$ alone and exposed to vehicle. (I) BRET experiments measuring the interaction between the 5-HT 6 R-YFP and Cdk5-Rluc in 
NG108-15 cells 24 (top) and 48 hours (bottom) after transfection. Data are from four experiments.

Fig. 2. GPRIN1 increases $5-H_{6} \mathrm{R}$ constitutive activity through Gs-cAMP signaling and promotes Gs binding to the receptor in NG108-15 cells. (A to $C$ ) The CAMYEL cAMP signal was measured in NG108-15 cells transfected with constructs encoding the $5-\mathrm{HT}_{6} \mathrm{R}$ (WT or W281A mutant) alone or in combination with a GPRIN1 construct 24 (A) or 48 hours (B and C) after transfection. Cells were treated with the TAT Ct320-342 peptide (10 $\mu \mathrm{g}$, applied in the cell medium for 24 hours) or $1 \mu \mathrm{M}$ WAY181187 for $5 \mathrm{~min}(\mathrm{~A})$, or the indicated concentrations of either WAY181187 or SB271046 (B) or vehicle (C) for $5 \mathrm{~min}$. (B) Left: Data were normalized to the amount of cAMP in cells that did not express GPRIN1 and were challenged with $1 \mu \mathrm{M}$ WAY181187. Right: Data were normalized to the basal amount of cAMP in cells not expressing GPRIN1. Data are means \pm SEM of values obtained at least three independent experiments performed on different sets of cultured cells. $* * P<0.01, * * * P<0.001$. (D and E) NG108-15 cells were transfected with constructs encoding either HA-tagged WT or W281A 5$\mathrm{HT}_{6} \mathrm{R}$ alone or in combination with the GPRIN1 construct and lysed 48 hours after transfection. (E) Cells were treated with control TAT peptide or TAT Ct-320-342 peptide $(1 \mu \mathrm{M}$, added 24 hours after transfection to the culture medium and incubated for 24 hours). 5- $\mathrm{HT}_{6} \mathrm{R}$ proteins were immunoprecipitated with agarose-conjugated anti-HA antibodies. The presence of GPRIN1 (D) or $\mathrm{G \alpha}_{\mathrm{s}}(\mathrm{E})$ in the immunoprecipitated samples was assessed by Western blotting analysis. Western blots are representative of three independent experiments. Bar graphs show means \pm SEM of immunoreactive signals measured in the three experiments. ${ }^{*} * *<0.001$ compared to 
cells co-expressing WT 5-HT6 R and GPRIN1 (D) and compared to cells co-expressing WT 5$\mathrm{HT}_{6} \mathrm{R}$ and GPRIN1 and exposed to the control TAT peptide (E).

Fig. 3. GPRIN1 interaction with the $5-H_{6} T_{6}$ promotes neurite growth and branching in a PKA-dependent manner in NG 108-15 cells. (A) NG108-15 cells were transfected with plasmids encoding GFP or YFP-tagged WT or W281A 5- $\mathrm{HT}_{6} \mathrm{R}$ alone or in combination with constructs encoding a dominant-negative Cdk5 mutant (Cdk5-DN, top) or GPRIN1 (bottom). GFP or receptor labelling is shown in cyan; GPRIN labelling is shown in magenta. Where indicated, cells were treated for 24 hours with the TAT Ct320-342 peptide $(1 \mu \mathrm{M})$. The images show fields representative of three independent experiments performed on different cultures. Scale bars, $50 \mu \mathrm{m}$. The graphs represent the branching index, measured as the number of intersections between dendrites and an overlaid concentric sphere, as a function of the distance from the soma. (B) Histogram showing the quantification of neurite length $(\mu \mathrm{m})$ in NG108-15 cells expressing the corresponding constructs and that were left untreated or were incubated with the TAT Ct320-342 peptide. At least 300 neurites were analyzed per condition. $* * * P<0.001$. (C) Correlation plots between neurite length and basal cAMP amounts in NG108-15 measured either 24 (left) or 48 hours (right) after transfection of the cells with the indicated constructs. (D) NG108-15 cells were transfected with plasmids encoding YFP-tagged WT 5-HT 6 or a mutant receptor incapable of coupling to G protein (Gs dead) alone or in combination with the GPRIN1 construct. Cells expressing the WT receptor were treated for 24 hours with $1 \mu \mathrm{M} \mathrm{SB} 271046,25$ $\mu \mathrm{M}$ RP-cAMP, or $2 \mu \mathrm{M}$ KT 5720. Cells were lysed 48 hours after transfection. Representative fields of three independent experiments performed on different sets of cultured cells are shown. Scale bars, $50 \mu \mathrm{m}$. The graphs represent the branching index, which was measured as described 
in (A). (E) The histogram shows the quantification of neurite length in the indicated conditions, which were from the experiments shown in (D). ${ }^{* * *} P<0.001$.

Fig. 4. Interaction between endogenous 5-HT 6 Rd and GPIN1 promotes neurite extension and the branching of striatal neurons. (A) Knockdown of GPRIN1 after infection of cultured mouse striatal neurons at DIV 4 by a virus expressing either control or two different GPRIN1specific shRNAs. The neurons were lysed at DIV 13 and GPRIN1 was detected by Western blotting analysis. The bar graph shows the mean \pm SEM of the GPRIN1 immunoreactive signal (normalized to the GAPDH immunoreactive signal) in each condition. $* * * * P<0.001$ compared to neurons expressing the scrambled shRNA. (B) Neurons were infected with either control (top) or GPRIN1-specific (middle and bottom) shRNAs. Neurons were fixed at DIV 13. GPRIN1 immunoreactivity is shown in magenta and MAP2 immunoreactivity in cyan. Scale bar, $5 \mu \mathrm{m}$. The graph shows the measurement of neurite branching, as assessed by Sholl analysis. The bar graph shows neurite length for neurons infected with control (black bar) or GPRIN1-specific shRNAs (white and gray bars). For both branching and neurite length, data are means $\pm \mathrm{SEM}$ of three independent experiments performed from different sets of cultured neurons with at least 300 neurites measured per conditions. $* * * P<0.001$. (C) Neurons were treated with either the control TAT peptide (top) or the TAT Ct320-342 peptide ( $1 \mu \mathrm{M}$, added to cultures at DIV 4; bottom), and fixed at DIV 13. GPRIN1 is shown in magenta and MAP2 in cyan. Neurite branching and length were determined and plotted as described in (B). ${ }^{*} P<0.05$.

Fig. 5. Schematic representation of the sequential interaction between the 5-HT $\mathbf{R}$ and either Cdk5 or GPRIN1 and its consequence on agonist-independent 5-HT 6 R-stimulated 
signaling. Association of the $5-\mathrm{HT}_{6} \mathrm{R}$ with $\mathrm{Cdk} 5$ results in receptor phosphorylation on a serine residue located in the receptor $\mathrm{C}$-terminal (Cter) domain, a necessary step in the agonistindependent, receptor-mediatd activation of $\mathrm{Cdc} 42$ signaling and initiation of neurite outgrowth (left), whereas the association of the receptor with GPRIN1 promotes the recruitment of activated $\mathrm{G \alpha}_{\mathrm{s}}$ and neurite extension and branching through an agonist-independent, PKAdependent mechanism (right). Nter, N-terminal. The application of an inverse agonist inhibits both pathways, indicating that these are dependent on the receptor's constitutive activity. 
A
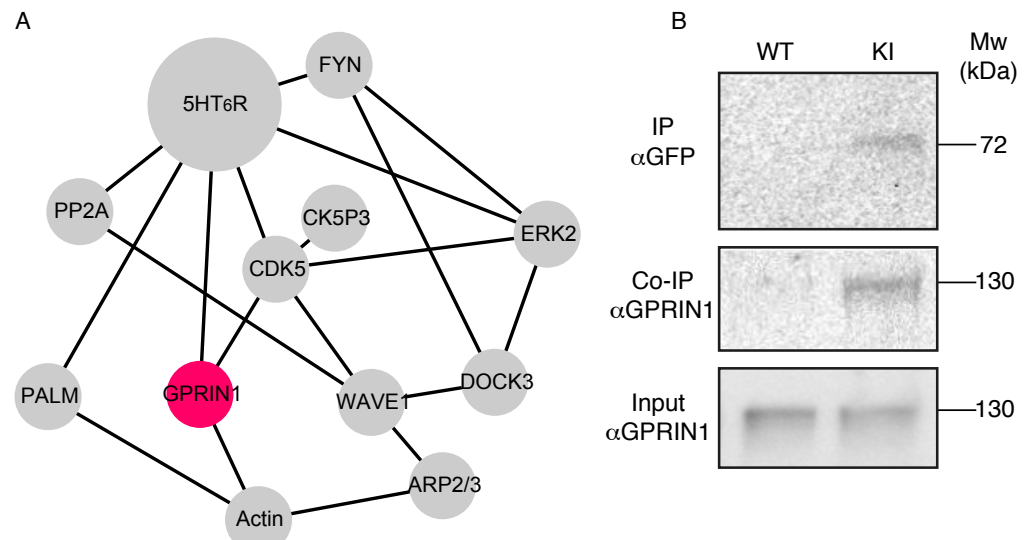

D
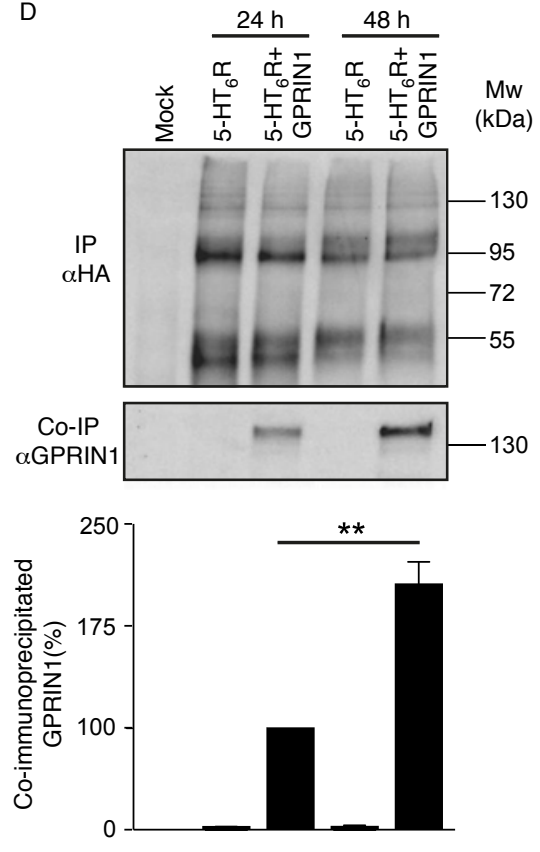

F
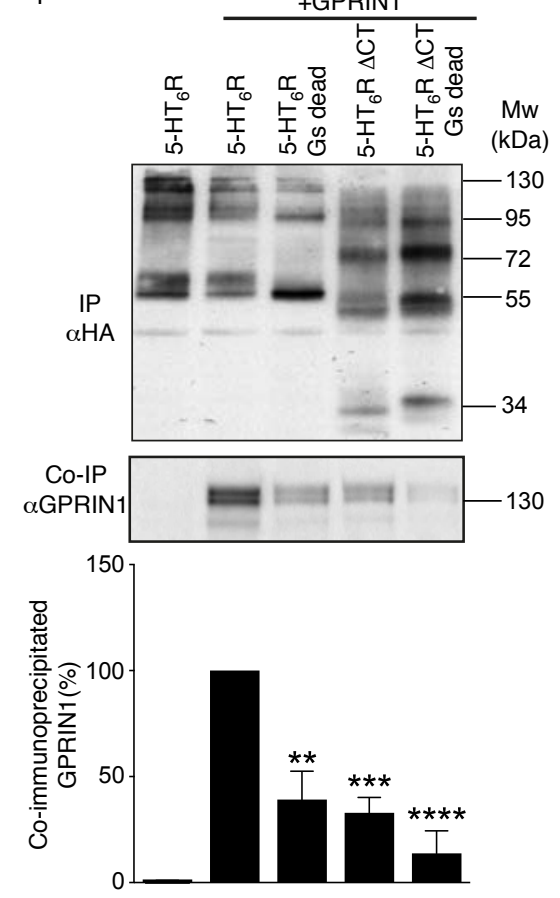

E
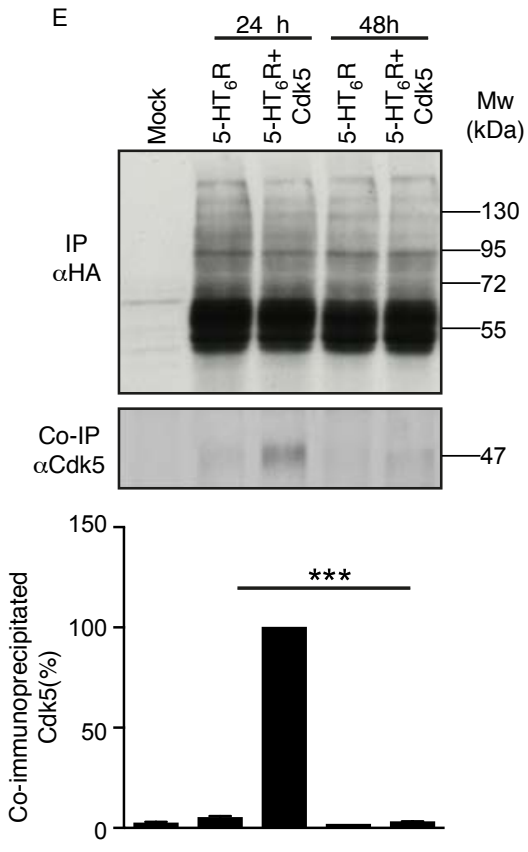

G

+GPRIN1

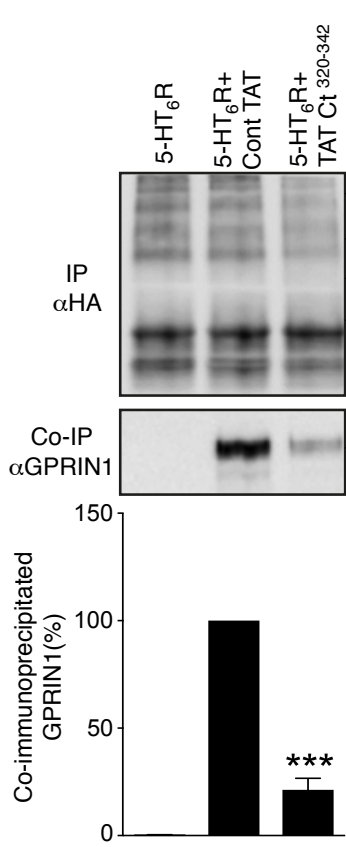

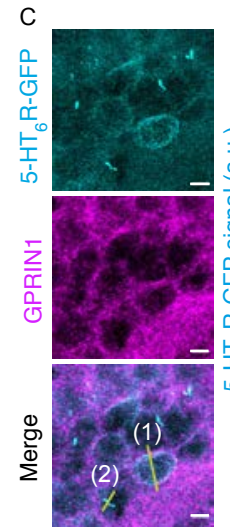

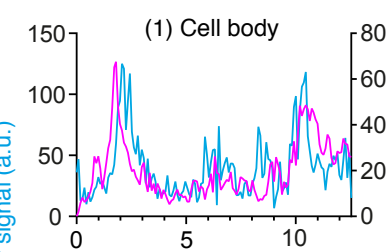

(2) Primary cilium

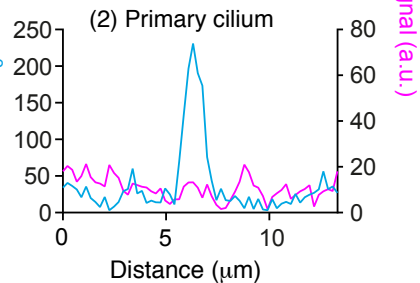

I
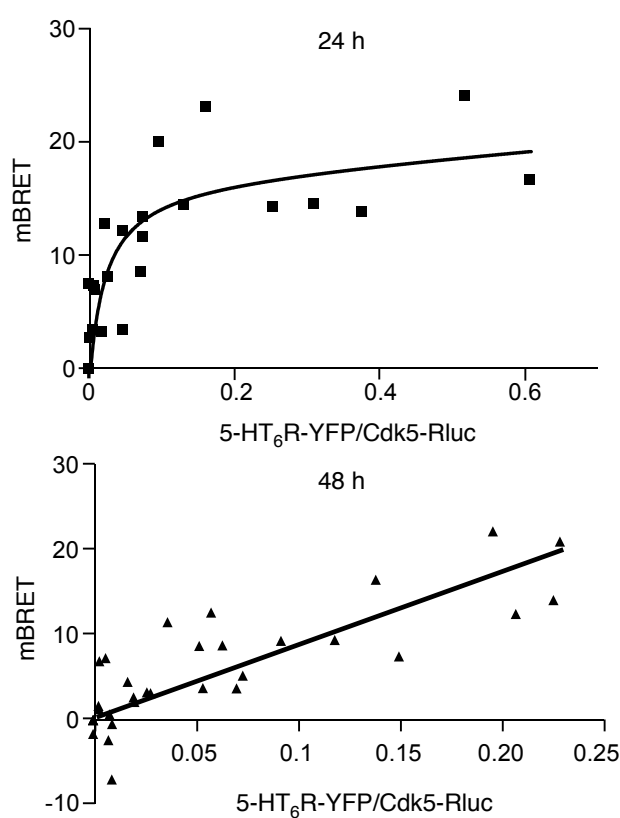

$\mathrm{H}$
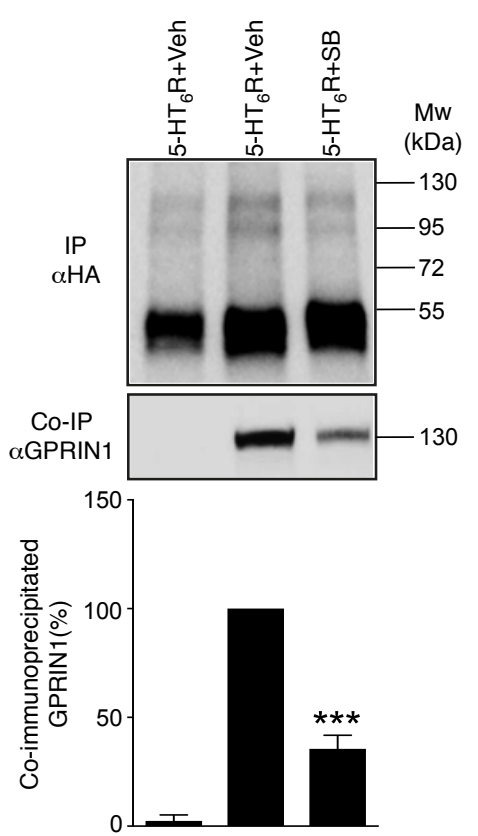


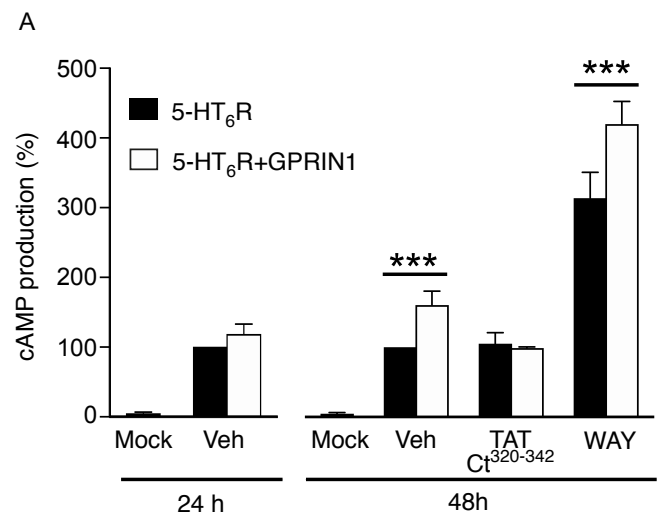

B

$\rightarrow 5-\mathrm{HT}_{6} \mathrm{R} \quad-\square-5-\mathrm{HT}_{6} \mathrm{R}+\mathrm{GPRIN} 1$

c

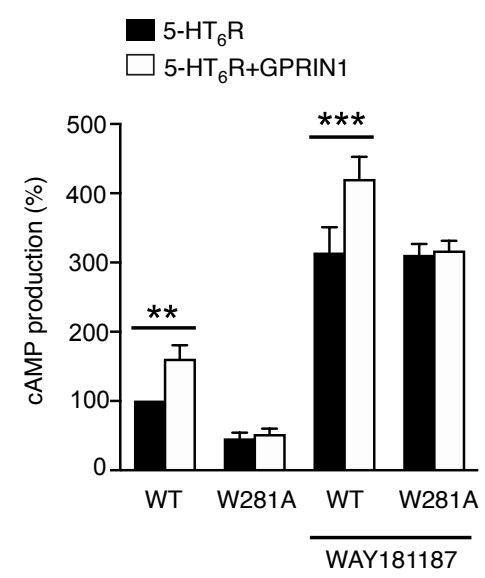

D

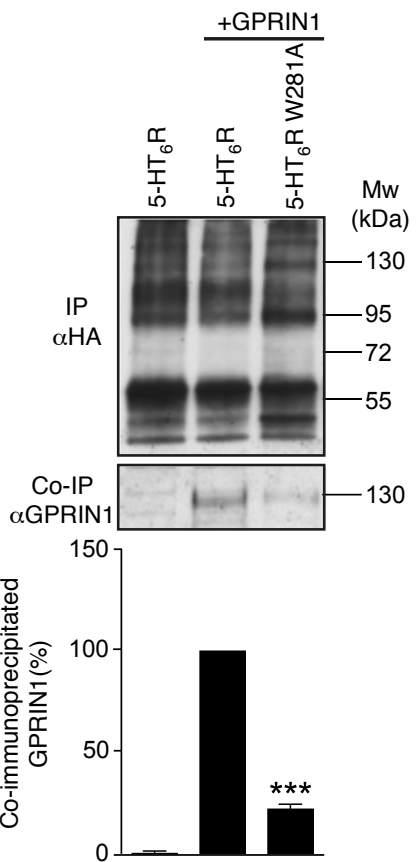

E
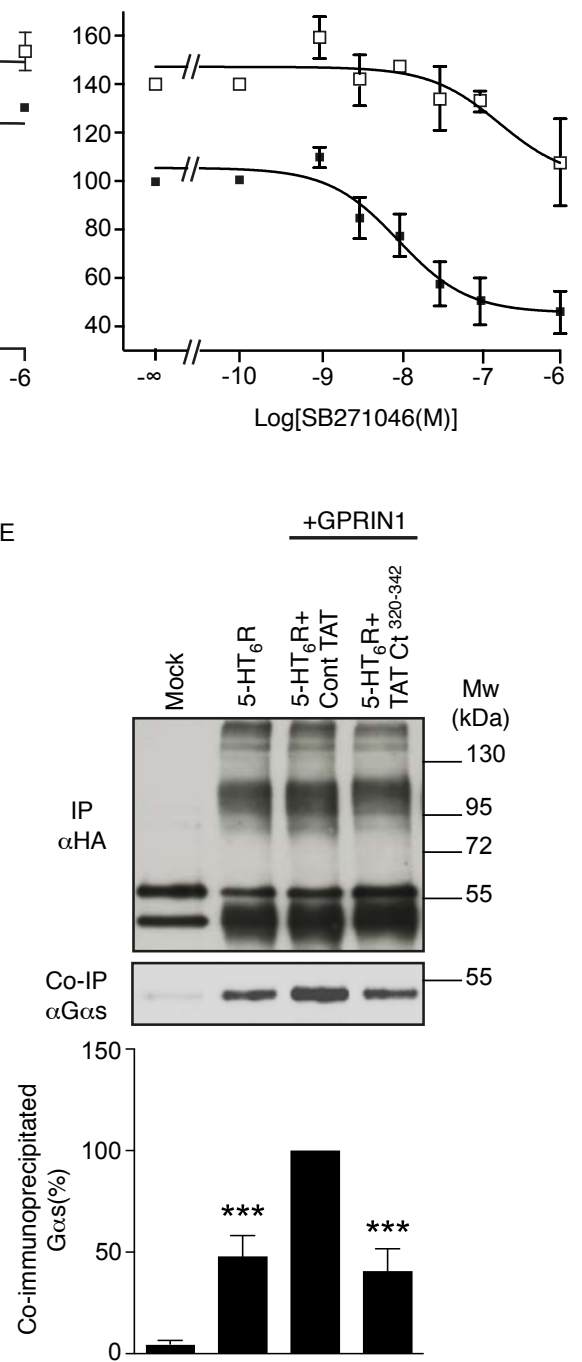


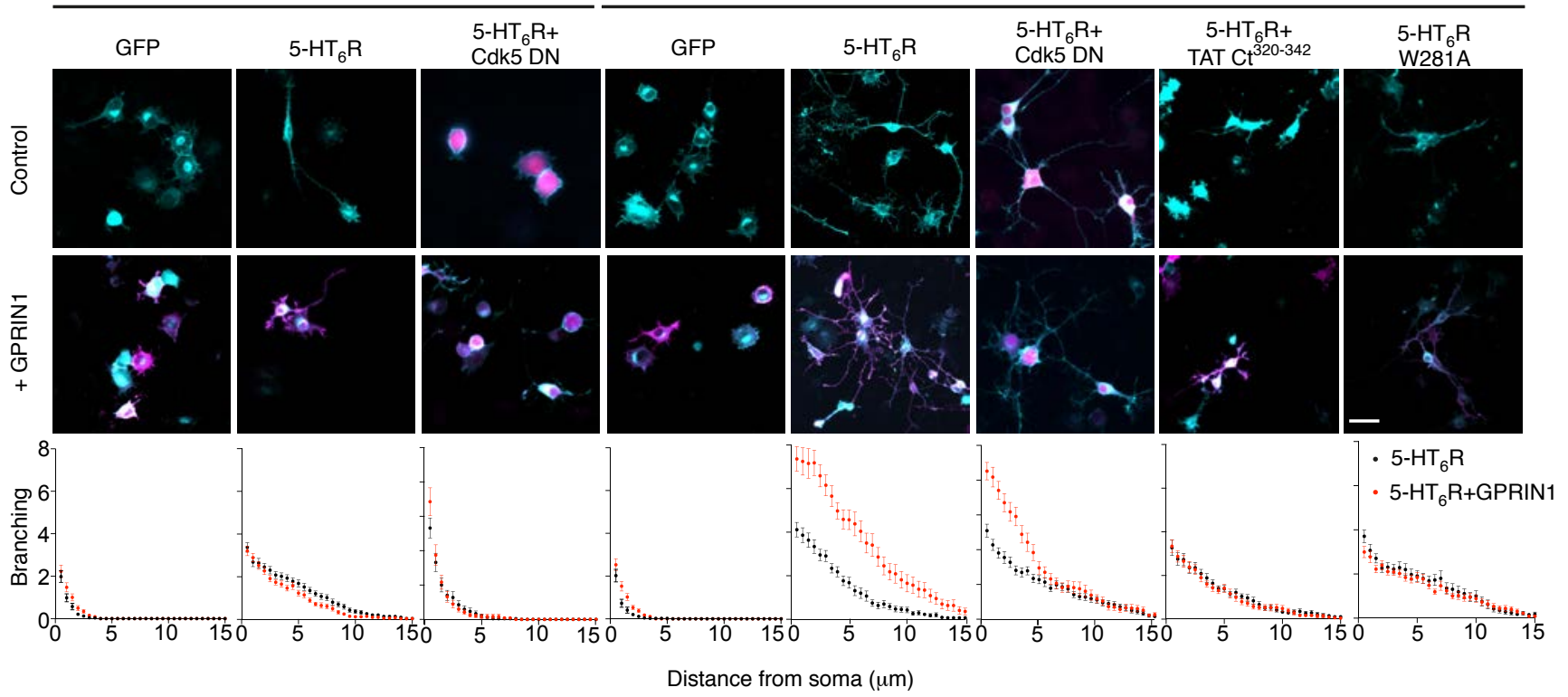

B

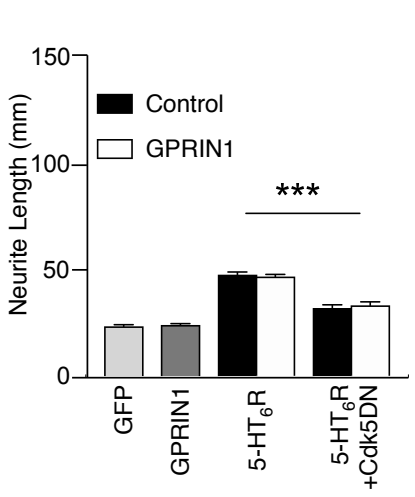

D

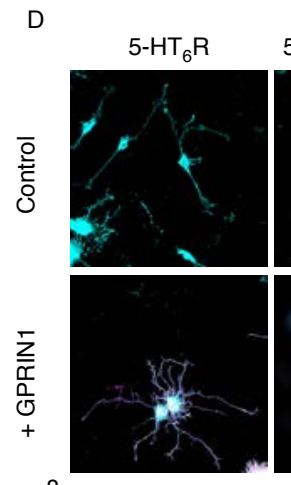

$5-\mathrm{HT}_{6} \mathrm{R}$ Gs dead

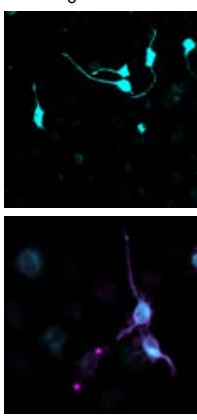

을
5- $\mathrm{HT}_{6} \mathrm{R}+$
SB271046

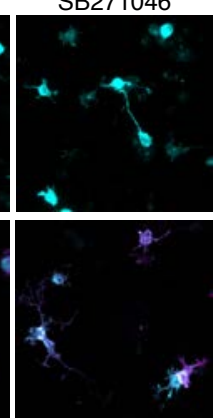

ar

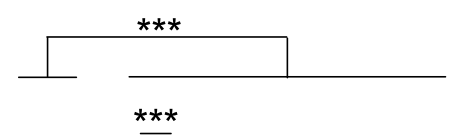

$48 \mathrm{~h}$

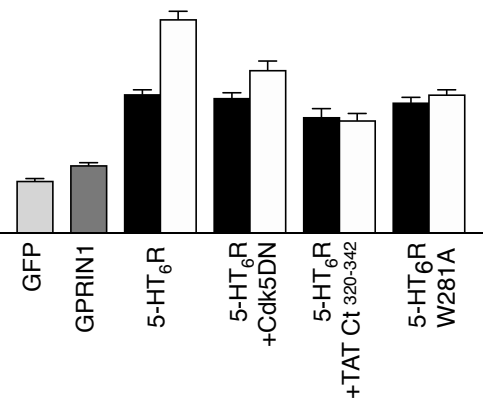

C

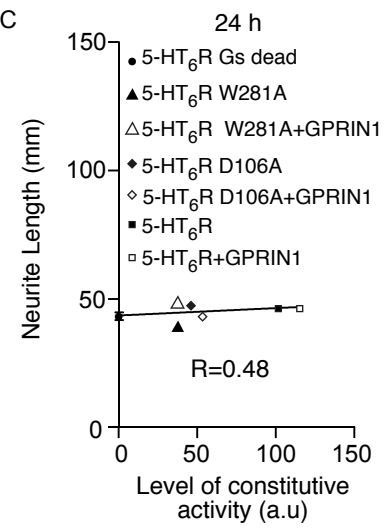

$48 \mathrm{~h}$

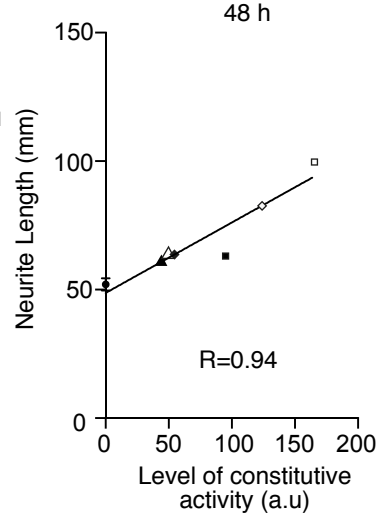

E

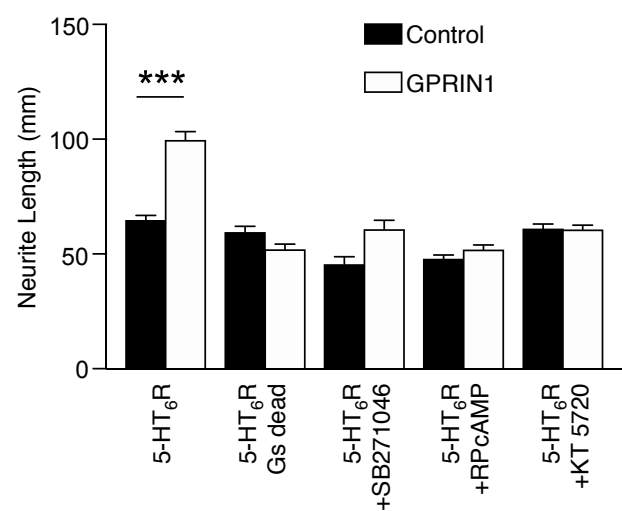


A

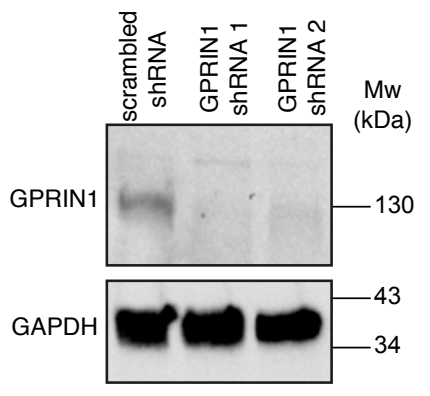

B
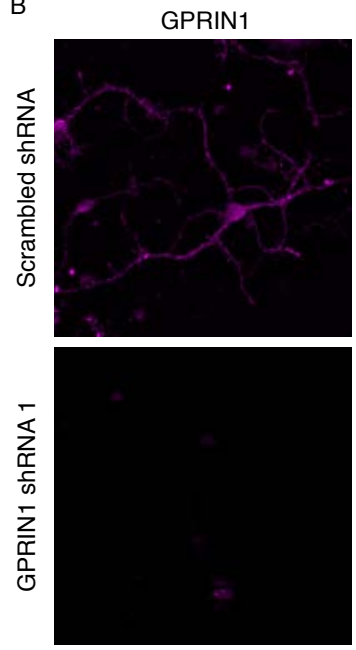

$N$
$\sum$
$\frac{1}{c}$
$\frac{1}{0}$
$\frac{z}{0}$
$\frac{0}{0}$
0

C
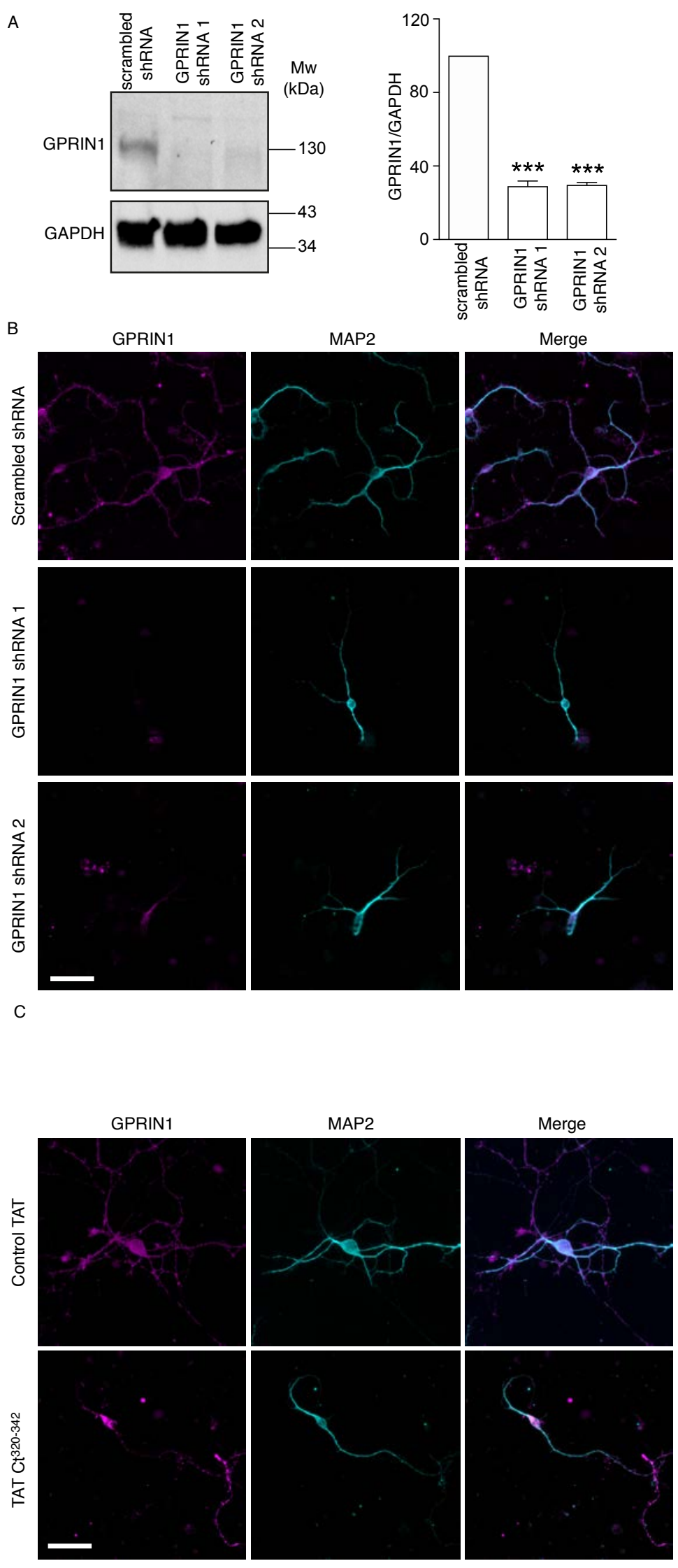

MAP2
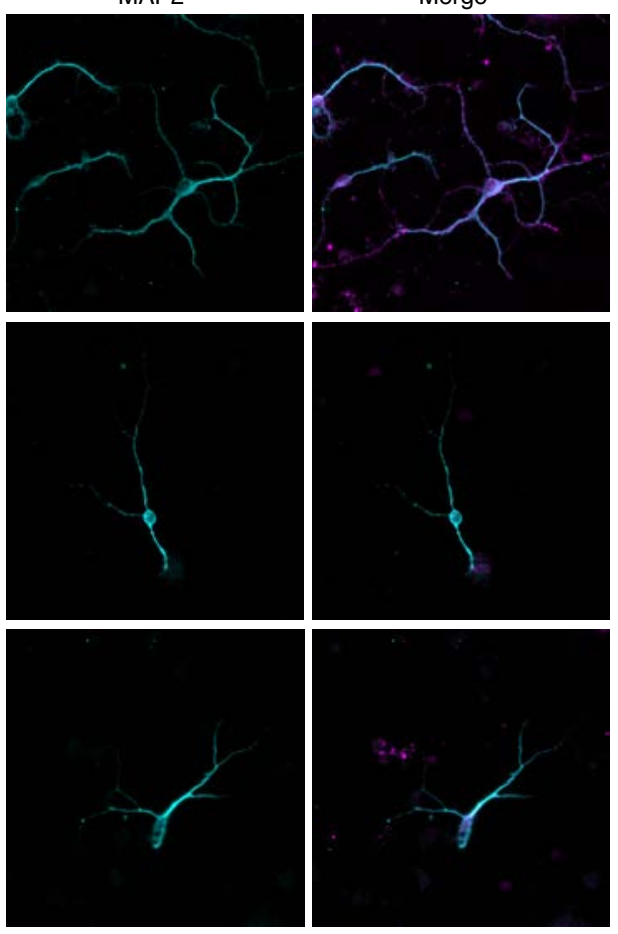
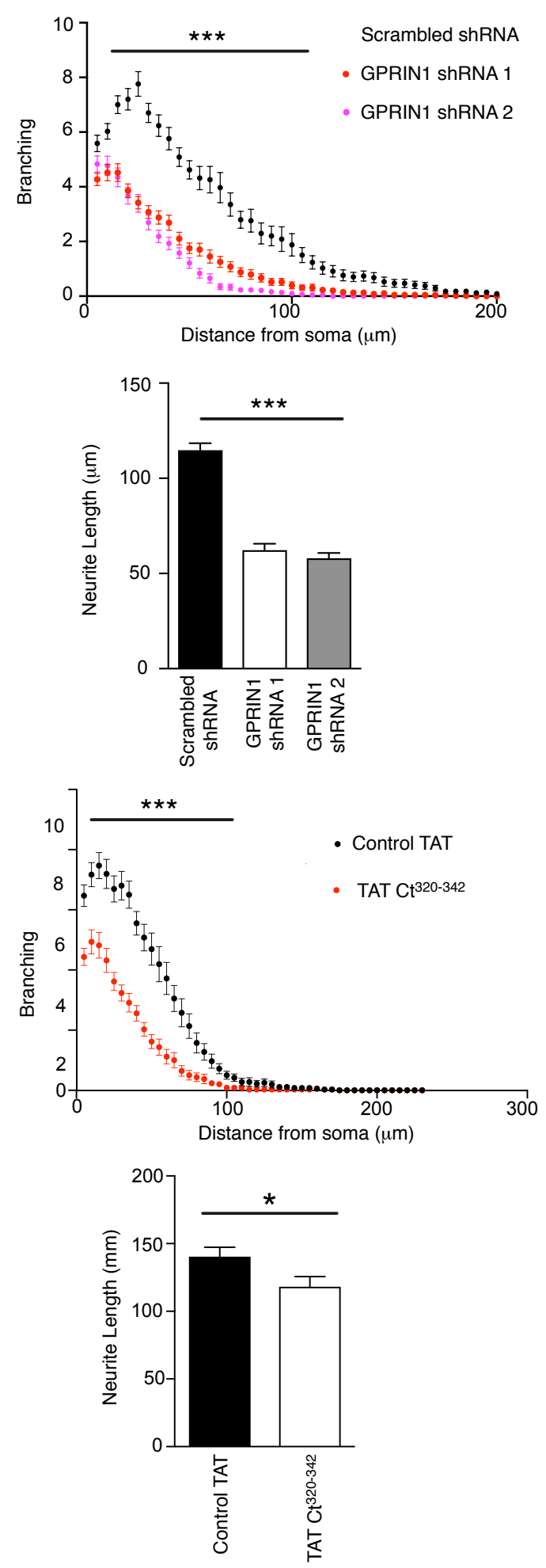

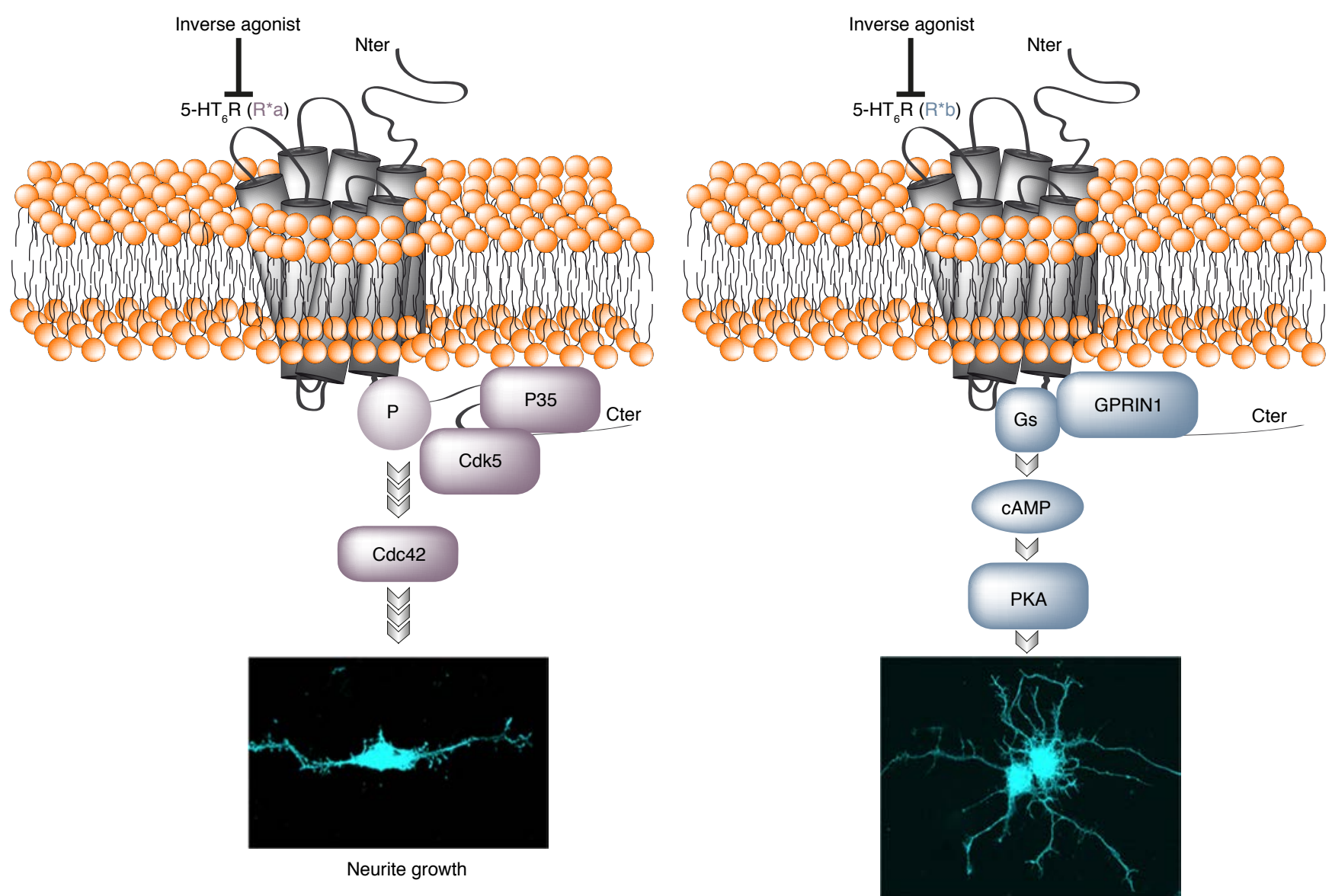

Neurite extension and Branching 